\title{
CONTINENTAL ENERGY TRADE: WHAT TO EXPECT FROM NAFTA 2.0
}

\author{
PAUl M. LALONDE, ${ }^{*}$ Yohai BAISBURD, ${ }^{* *}$ JOAQUIN CONTRERAS, ${ }^{* * *}$ \\ JORGE JIMENEZ, ${ }^{* * * *}$ AND VEDIA BITON EIDELMAN ${ }^{* * * * *}$
}

\begin{abstract}
The implementation of the North American Free Trade Agreement (NAFTA) in 1994 significantly impacted the North American energy market via the provisions of Chapter 6 . The original agreement with respect to Chapter 6 included three important principles: (1) a full respect for the constitutional restrictions of each party; (2) the need to strengthen and increase trade of energy products and services through gradual and sustained liberalization; and (3) the need to create competitive energy sectors. This article examines whether NAFTA continues to serve the interests of the three signatory states and whether potential changes are necessary or would be beneficial. In addition, the authors take an in-depth look at the energy markets of each North American country on an individualized basis. In particular, the authors examine the respective energy industry backgrounds, legal frameworks for natural resource regulation, and trends in the energy markets for Canada, Mexico, and the United States.
\end{abstract}

\section{TABLE OF CONTENTS}

I. INTRODUCTION . . . . . . . . . . . . . . . . . . . . . . 276

II. The Evolving State of Global AND

NORTH AMERICAN ENERGY MARKETS 1994-2017 . . . . . . . . . . . . 276

III. TRAdE AND INVESTMENT Flows In ENERGy MARKETS . . . . . . . . . . . . 277

A. Oil And Gas Since $1994 \ldots \ldots \ldots \ldots \ldots \ldots \ldots \ldots \ldots \ldots$

B. ELECTRICITY . . . . . . . . . . . . . . . . . . . . . . 278

C. RENEWABLES . . . . . . . . . . . . . . . . . . . . . . . . . . . . . 279

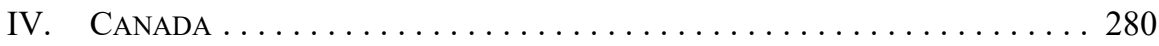

A. OIL AND GAS INDUSTRY:

BACKGROUND AND GENERAL MARKET INFORMATION $\ldots \ldots \ldots 280$

B. LEGAL FRAMEWORK OF

Canadian Natural Resources $\ldots \ldots \ldots \ldots \ldots \ldots \ldots \ldots \ldots 28$

V. MEXICO . . . . . . . . . . . . . . . . . . . . . . . . . . 284

A. BACKGROUND OF OIL AND GAS INDUSTRY AND GENERAL

INFORMATION OF CURRENT MARKET: PRODUCTION . . . . . . . 284

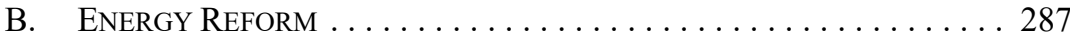

C. LEGAL FRAMEWORK $\ldots \ldots \ldots \ldots \ldots \ldots \ldots \ldots \ldots \ldots \ldots$

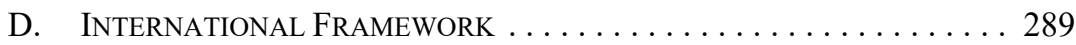

E. ForEIGN TRADE ACTIVITIES: IMPORTS AND EXPORTS . . . . . . . . . 294

F. CURRENT TRENDS AND InVESTMENT OPPORTUNITIES . . . . . . . . 295

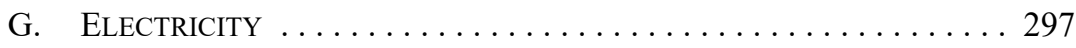

VI. UNITED StATES . . . . . . . . . . . . . . . . . . . . . . . . . . . . . 298

* $\quad$ LLB, Dentons Canada LLP, Toronto.

*** JD, Cassidy Levy Kent (USA) LLP, Washington, DC.

*** JD, LLM, Dentons Lopez Velarde, Mexico City.

***** JD, LLM, Dentons Lopez Velarde, Mexico City.

***** JD, MA, Dentons US LLP, Washington, DC. 

A. BACKGROUND OF OIL AND GAS INDUSTRY AND
GENERAL INFORMATION OF CURRENT MARKET FOR
OIL AND GAS PRODUCTION . . . . . . . . . . . . . . . . . . . . . . . . 299
B. LEGAL FRAMEWORK . . . . . . . . . . . . . . . . . 300
C. Current Trends And Investment Opportunities . . . . . . . 303

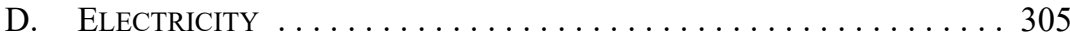
E. RenEWABLES ........................ 306

VII. SUMMARY OF CURRENT NAFTA's CHAPTER $6 \ldots \ldots$. . . . . . . . . . . . 309

A. Negotiating BAckground . . . . . . . . . . . . . . . . . . 309

B. SuMMARY of Key Provisions . . . . . . . . . . . . . . . . 310

VIII. Negotiating OBJECTIVES FOR CHAPTER 6 AND

SPECTRUM OF LiKELY OUTCOMES FOR AN ENERGY CHAPTER 53 . . . . . 311

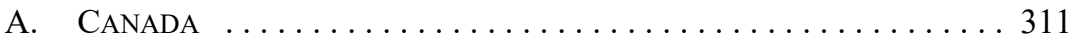

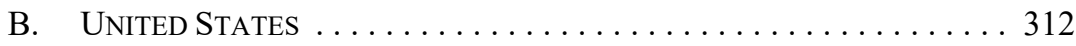

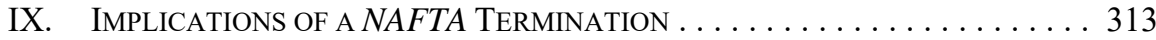

X. Conclusions ANd ReCOMMENDATIONS . . . . . . . . . . . . . . . 313

\section{INTRODUCTION}

This article reviews the state of the North American energy market since the implementation of the North American Free Trade Agreement in 1994. ${ }^{1}$ It summarizes the main elements of the legal framework within which the oil and gas, electricity, and renewables markets operate on the continent and assesses whether and how the provisions of Chapter 6 of NAFTA continue to serve the interests of the three signatory states. The article will inventory the known priorities of Canada, Mexico, and the United States in relation to NAFTA's energy provisions and assess the likely outcomes of the negotiations. Finally, the article will review the likely implications of a termination of NAFTA on the energy sector and provide insights into what industry actors should do to prepare for the various realistic outcomes of the negotiations.

\section{The Evolving State of Global And NORTH AMERICAN ENERGY MARKETS 1994-2017}

Following the Second World War, the trade relations of Canada, Mexico, and the US were based on the General Agreement on Tariffs and Trade. ${ }^{2}$ In 1989, Canada and the US created a free trade agreement, the Canada-U.S. Free Trade Agreement ${ }^{3}$ that consisted of various obligations respecting tariff elimination, standards, government procurement, services (including financial services), investment, and the application of special review mechanisms for trade remedies. ${ }^{4}$ Similarly, the government of Mexico entered into a free trade negotiation with the US in $1991 .{ }^{5}$ Canada requested involvement which ultimately established NAFTA.

North American Free Trade Agreement Between the Government of Canada, the Government of Mexico and the Government of the United States, 17 December 1992, Can TS 1994 No 2 (entered into force 1 January 1994) [NAFTA].

30 October 1947, 58 UNTS 187 (entered into force 1 January 1948) [GATT].

2 January 1988, Can TS 1989 No 3 (entered into force 1 January 1989) [CUSFTA]

Jon R Johnson, International Trade Law (Concord, Ont: Irwin Law, 1998) at 31.

Ibid. 
Oil has been, and continues to be, the world's dominant fuel, but it has been losing market share since the 1970s. ${ }^{6}$ As with other commodities, supply and demand have been impacted, "primarily by the rate and distribution of global economic growth" and with technological advances, "such as the emergence of nuclear power or advances in deepwater exploration, development, and production capability." According to Mark Finley in "The Oil Market to 2030 - Implications for Investment and Policy," "[p]opulation and income growth are the two most powerful driving forces behind the demand for energy.... Over the last 20 years world population has increased by 1.6 billion people, and it is projected to rise by 1.4 billion over the next 20 years." 8

The North American oil and gas industry has undergone dramatic changes since NAFTA was first established over 20 years ago. Specifically, the US has substantially increased resource production and is now the world's leading producer of oil and natural gas. Mexico has finally opened its energy sector to foreign and domestic private investment and Canada has become a top six global producer of oil and gas.

\section{Trade ANd InVestment Flows in EnERgy Markets}

\section{A. OIL ANd Gas Since 1994}

In 2016, global energy investments accounted for 2.2 percent of global GDP (US\$1.7 trillion). ${ }^{9}$ This was 12 percent down from what the International Energy Agency (IEA) recorded in the year prior. ${ }^{10}$ In the same year, China remained the largest destination of energy investment (21 percent of global total) followed by the US, Europe, India, Russia, and Southeast Asia. ${ }^{11}$

Between 2014 and 2016, there was a 44 percent plunge in upstream oil and gas investments. At the same time, there was a 53 percent upswing in US shale investment and large spending in the Middle East and in 2017, investments in Russia were expected to increase by 3 percent. ${ }^{12}$ According to Forbes, upstream investment has been "ignited by firmer oil prices which triggered a flood of capital into Permian operators over the last 12 months." 2018 could see further increased opportunities for investors: 50 billion barrels of oil equivalent reserves have been found which could be sanctioned in 2018 or $2019 .{ }^{14}$ This is combined with ongoing projects such as Liza (Guyana Oil) and the Leviathan (Israel Gas). ${ }^{15}$

\footnotetext{
$6 \quad$ Mark Finley, “The Oil Market to 2030 - Implications for Investment and Policy” (2012) 1:1 Economics Energy \& Environmental Policy 25 at 26.

Ibid.

Ibid at 27.

International Energy Agency, World Energy Investment 2017 Executive Summary (Paris: IEA Publications, July 2017) at 2 [IEA, World Energy Investment].

Ibid.

International Energy Agency, "World Energy Investment 2017” (11 July 2017), online: <https://www. iea/org/publications/wei2017/>.

Ibid.

Simon Flowers, "Investment in Upstream Starting To Pick Up," Forbes (25 September 2017), online: $<$ https://www.forbes.com/sites/woodmackenzie/2017/09/25/investment-in-upstream-starting-to-pickup/>.

Ibid.

Ibid.
} 


\section{B. ELECTRICITY}

\section{TRENDS AND INVESTMENT OPPORTUNITIES}

Electricity, and investment in it, is entering a new era; the IEA expects that it will grow substantially over the next two decades, and particularly over the next five years. The IEA expects that by 2022 , electricity will be a primary investment above hydro and wind, and by 2040 , electricity consumption will see the same growth that oil saw over the last 25 years. ${ }^{16}$

In 2016, the electricity sector edged ahead of the oil sector for the first time in history. Globally, electricity investment edged down by just under 1 percent to US\$718 billion. US\$297 billion was invested in renewables-based power capacity which "remained the largest area of electricity spending, despite falling back by $3 \%$." 17

Similarly, investment in electricity networks and storage continued to increase in 2016, as it has over the past five years, reaching an all-time high of US\$277 billion. ${ }^{18}$ China accounted for 30 percent of the network spending and Europe made up 13 percent. ${ }^{19}$

Electricity policies in the Organisation for Economic Co-operation and Development countries, particularly over the last decade, have focused on the liberalization of electricity markets; therefore, governments have attempted to shift away from entirely state owned monopolies to private investors. ${ }^{20}$ Evidence demonstrates that this liberalization of the energy market has "led to a reduction in operating costs of generating plants by improving labour productivity, reducing maintenance costs and improving fuel purchasing strategies." ${ }^{21}$ The current and expected increases in electrical uses have created opportunities for potential investors - specifically, as the role of electricity and its demand increases globally, technology and innovation create new opportunities. ${ }^{22}$

Currently, the transmission and distribution business (that is, linking power plants to businesses and residences via critical infrastructure), has proven to be a relatively safe investment for investors (including Warren Buffett). ${ }^{23}$ Companies operate wires and transmission towers that deliver electricity and receive a return on investment from rates that are set by governments. In the US alone, 42,000 miles of high voltage wire to the country is

16 International Energy Agency, Renewables 2017 Analysis and Forecasts to 2022 (Paris: IEA Publications, 2017) at 15 [IEA, Renewables 2017]. See also International Energy Agency, "World Energy Outlook 2017” (14 November 2017), online: <https:/www.iea.org/weo2017> [IEA, "WEO 2017'].

IEA, World Energy Investment, supra note 9 at 3.

Ibid.

Ibid.

International Energy Agency \& Organisation for Economic Co-operation and Development, Power Generation Investment in Electricity Markets (Paris: OECD/IEA, 2003) at 3.

Ibid at 21.

Michael Waldron \& Yoko Nobuoka, "Commentary: Changing Utility Business Models and Electricity Investment in Europe" (15 December 2017), online: International Energy Agency $<$ https://www.iea.org/ newsroom/news/2017/december/commentary-changing-utility-business-models-and-electricityinvestment.html>.

$23 \quad$ Tom DiChristopher, "Why Billionaire Investors Like Warren Buffett are Chasing After This Energy Investment," CNBC (22 August 2017), online: <https://www.cnbc.com/2017/08/22/why-investors-likewarren-buffett-are-investing-in-electricity-transmission.html $>$. 
needed which will cost more than US\$8.5 billion per year over ten years. ${ }^{24}$ Electricity demand is expected to increase rapidly in the regions of China, India, Southeast Asia, the Middle East, and Africa over the next few decades. ${ }^{25}$

\section{RENEWABLeS}

\section{TRENDS AND OPPORTUNITIES}

Over the last decade, projects delivering clean and renewable energy have become a credible low carbon alternative. The industry received record high investment in such alternatives in 2015 when the Paris Agreement was executed. While the future of the Paris Agreement is unknown (the Trump administration plans on opting out), clean and renewable energy remains a strong force in global investment opportunities. Over the last decade, renewable energy has gone through a revolution, from being labelled as "alternative energy" only for wealthy countries, to the majority (55.3 percent in 2016) of new generating capacity installed worldwide. ${ }^{26}$

Following the record high year in 2015, renewable investment dipped in $2016 .{ }^{27}$ Investments in 2016 were primarily from new renewable sources of wind, solar, biomass, waste, geothermal, small hydro, and marine which accounted for 55.3 percent of all gigawatts of new power generation. ${ }^{28}$ Despite the dip in 2016 , the year saw a record US $\$ 110.3$ billion of acquisition deals, including purchases of renewable energy generating plants, refinancings, and corporate mergers and takeovers, which made the total value of transactions reach US\$351.9 billion. $^{29}$ Global investment in clean energy in 2017 was US\$333.5 billion. ${ }^{30}$ US $\$ 160.8$ billion was made up of solar technologies, but also recordbreaking deals were in offshore wind. ${ }^{31}$

The global increase in renewable energy can be attributed, in great part, to China which has largely been driven by concerns about air pollution. ${ }^{32}$ Half of the global solar photovoltaic system demand is from China, and Chinese companies account for around 60 percent of total annual solar cell manufacturing capacity globally. ${ }^{33}$ The US remains the second largest growth market despite policy uncertainty. ${ }^{34}$ Over the next five years the renewable energy market will grow substantially. According to the IEA, growth in renewable generation will be twice as large as that of gas and coal combined by $2022 .{ }^{35}$

Ibid.

IEA, "WEO 2017," supra note 16.

UN Environment Economy Division, Global Trends in Renewable Energy Investment 2017 (Frankfurt: Frankfurt School - UNEP Collaborating Centre, 2017) at 19.

Ibid at 34, figure 25 .

Ibid at $32-33$.

Ibid at 14.

"Runaway 53GW Solar Boom in China Pushed Global Clean Energy Investment Ahead in 2017," Bloomberg New Energy Finance (16 January 2018), online: <https://about.bnef.com/blog/runaway$53 \mathrm{gw}$-solar-boom-in-china-pushed-global-clean-energy-investment-ahead-in-2017/>.

Ibid.

IEA, “WEO 2017," supra note 16.

IEA, Renewables 2017, supra note 16 at 13.

Ibid at 14.

Ibid at 15 . 
While growth in renewable energy is clearly evident, a shift in policies, particularly from the US with regards to the Paris Agreement and federal tax reforms, makes the future of renewable energy markets volatile.

\section{Canada}

\section{A. OIL AND GAS INDUSTRY:}

\section{BACKGROUND AND GENERAL MARKET INFORMATION}

Canada and the US share the longest undefended border on the planet, running $8,891 \mathrm{~km}$ long. ${ }^{36}$ The two countries also share the world's second largest trading relationship. ${ }^{37}$ In 2016, CDN\$727.8 billion was traded between the two countries. Seventy-five percent of Canada's exports were destined south of the border and 66 percent of Canadian imports came from the US foreign trade, and foreign trade accounts for more than 50 percent of Canada's GDP. ${ }^{38}$

The Canadian oil and gas industry is a significant contributor to both the provincial and federal economies - this will not change for the foreseeable future. The IEA says that crude oil is the lifeblood of the modern economy that accounts for the largest share of the total world primary energy demand and will remain so until approximately $2040 .{ }^{39}$

The Canadian economy is substantially affected by global trends in both natural gas and oil. According to the Canadian Energy Research Institute, CDN\$380 billion of capital investment and CDN\$1.8 trillion of operational revenues from Canadian oil and gas projects over the next 11 years will be invested in the industry..$^{40}$ This will generate CDN\$2.7 trillion in Canadian GDP and more than 6,500 thousand person-years in Canada. "For every direct job created in the Canadian oil and gas sector, 2 indirect and 3 induced jobs in other sectors are created in Canada on average." 42 Similarly, for every CDN\$1 million invested and generated in the Canadian oil and gas sector, the Canadian GDP impact is CDN\$1.2 million. ${ }^{43}$ While it remains a critical industry for Canada, it has been significantly impacted by declining prices and the "shale revolution" that has occurred in the US. ${ }^{44}$

Canadian Energy Research Institute, Economic Impacts of Canadian Oil and Gas Supply in Canada and the US (2017-2027), by Ganesh Doluweera, Paul Kralovic \& Dinara Millington, Study No 166 (Calgary: CERI, August 2017) at ix [CERI, Economic Impacts].

lain Marlow, "China Passes Canada to Become Largest U.S. Trading Partner," The Globe and Mail (5 November 2015), online: $<$ https://www.theglobeandmail.com/report-on-business/international-business/ asian-pacific-business/china-passes-canada-as-uss-largest-trading-partner/article27134249>.

Atif Kubursi, "Why Canada Has a Lot to Lose in NAFTA Renegotiations," Maclean's (11 August 2017), online: <https:/www.macleans.ca/economy/why-canada-has-a-lot-to-lose-in-the-nafta-renegot iations $>$. See also JLL Research, "NAFTA \& Canada - What's Next?" (2017), online: <www.jll.ca/ canada/en-ca/Research/CAN-NAFTA-Spring-2017-JLL.pdf>. Canadian Association of Petroleum Producers, "Crude Oil Forecast, Markets and Transportation" (2017) at 1, online: <www.oscaalberta.ca/wp-content/uploads/2017/06/CAPP-2017-Crude-Oil-Forecast.pdf > [CAPP, "Crude Oil Forecast"].

$40 \quad$ CERI, Economic Impacts, supra note 36 at 63.

41 Ibid.

42 Ibid.

43 Ibid.

$44 \quad$ Ibid at 31 


\section{CRUde Oil in CANAdA}

Canada has the third largest reserves of crude oil in the world and according to the Oil and Gas Journal it is the sixth largest global producer. ${ }^{45}$ Of the $1,706.7$ billion barrels of proved reserves, Canada has 171.5 billion, or 10 percent of the world's share of proved reserves. ${ }^{46}$ When NAFTA was implemented in 1994, Canada exported 1.27 million barrels a day $(\mathrm{m} \mathrm{b} / \mathrm{d})$ to the US; by 2000 , Canada was exporting $1.81 \mathrm{~m} \mathrm{~b} / \mathrm{d}$; and by $2005,2.18 \mathrm{~m} \mathrm{~b} / \mathrm{d}$. ${ }^{47}$ More recently, in 2016 , Canada exported $3.85 \mathrm{~m} \mathrm{~b} / \mathrm{d}$ and by 2030 , Canada expects to export $5.12 \mathrm{~m}$ $\mathrm{b} / \mathrm{d}^{48}$

Canadian crude oil is primarily from the Western region (Alberta); however, approximately 5 percent is sourced from Eastern Canada. "Crude oil from Eastern Canada is sourced primarily from three oil fields located offshore of Newfoundland and Labrador."49 While the 2016 Fort McMurray wildfires noticeably impacted Alberta oil sands production, the year still saw an overall growth, and by 2040 it is expected to grow to $4.9 \mathrm{~m} \mathrm{~b} / \mathrm{d}$ from 2.6 $\mathrm{m} \mathrm{b} / \mathrm{d}$ in $2016^{50}$

\section{NATURAL GAS}

Canada is one of the largest producers of natural gas in the world. The 2017 BP statistical review ranked Canada fifth in the world, producing 4.3 percent of global production, ranking behind the US (21.1 percent), Russia (16.3 percent), Iran (5.7 percent), and Qatar (5.1 percent). ${ }^{51}$

Currently, Canada only exports natural gas to the US; however, the natural gas industry is seeking new markets where the gas can be exported overseas in a liquefied form to provide Canada with future economic growth opportunities, both internationally as the global demand for natural gas is expected to increase 45 percent by 2040, and domestically as implementing such changes would employ thousands. ${ }^{52}$ The Canadian Association of Petroleum Producers stated that one upstream natural gas plant that exports 2 billion cubic feet per day $(\mathrm{Bcf} / \mathrm{d})$ "would provide 20,000 direct, indirect and induced B.C. jobs, about $\$ 475$ million in annual payments to the B.C. government, and add \$3.7 billion to B.C.'s GDP." 53 Between 2017 and 2027, total Canadian GDP from the natural gas industry is estimated to be CDN\$422.5 billion. ${ }^{54}$

CAPP, "Crude Oil Forecast," supra note 39 at 3.

BP, "BP Statistical Review of World Energy June 2017" (2017) at 12, online: <https://www.bp.com/ content/dam/bp/en/corporate/pdf/energy-economics/statistical-review-2017/bp-statistical-review-ofworld-energy-2017-full-report.pdf $>$ [BP, BP Statistical Review].

Joseph M Dukert, "North American Energy, 2000-2007: What a Difference Those Years Make!" (2007) 37:1 American Rev Can Studies 57 at 64.

Alpha Sow, "One Past, Many Futures: The Outlook for Oil According to BP, Statoil, IEA, EIA, CAPP" (June 2017) at 4, online: <www.ceri.ca/assets/files/Crude_Oil_Report_June_2017.pdf $>$.

CAPP, "Crude Oil Forecast," supra note 39 at 5.

National Energy Board, "Canada's Energy Future 2017 Supplement," (2018) at 3, 11, online: <https:// www.neb-one.gc.ca/nrg/ntgrtd/ftr/20171snds/nrgftrs2017spplmnts2017lsnds-eng.pdf $>$. BP, BP Statistical Review, supra note 46 at 28.

Canadian Association of Petroleum Producers, "Canada's Natural Gas" (July 2018) at 27, 31, online: $<$ https://www.capp.ca/initiatives/canadas-natural-gas $>$.

Ibid at 28 .

Ibid at 31 . 


\section{B. LEGAL FRAMEWORK OF \\ Canadian Natural Resources}

In Canada, energy administration takes place at both the federal and provincial levels. Many of the Canadian energy responsibilities are shared between both levels of government. In 1994, the federal government created Natural Resources Canada (NRCan) through the Department of Natural Resources Act. ${ }^{55} \mathrm{NRCan}$ is a leading department on energy policy for the federal government and it deals with the responsible development of Canada's natural resources, including energy. ${ }^{56}$

Ultimately, Canadian provincial governments are the owners of the ground resources within the territory (not including natural resources located on Aboriginal grounds) and therefore, provincial governments are entrusted with the responsibility of drafting policies and regulating the industry. The provincial governments control most of the upstream and downstream activities. "Provincial regulators have jurisdiction over their province's energy generation, intra-provincial transmission, distribution, retail pricing, and wholesale markets. ${ }^{57}$ Provincial governments often use this authority to contract private corporations to manage natural resources. For example, in October of 2015, Ontario Premier, Kathleen Wynne, privatized the province's electricity transmission and distribution industry. As of 2011, one quarter of all Canadian generation capacity was privatized while the rest came from recognizable public utilities. "[B]y 2020, private generation is set to rise to more than a third, or 36 per cent, of Canada's power output." 59

Canadian provinces either employ a vertical or horizontal structure to the electricity market. In provinces with vertically integrated markets, Crown corporations are the principal entities. For example, British Columbia has BC Hydro and Saskatchewan has SaskPower these companies dominate the electricity market in their respective provinces ${ }^{60}$ Conversely, Ontario operates a horizontal electricity market; Ontario Power Generation is a Crown corporation which owns about 50 percent of the generating capacity in Ontario while Hydro One (the owner and operator of the provincial transmission grid) owns the remaining 50 percent. $^{61}$

Similarly, the Canadian natural gas market is fully liberalized - investment is open to both private and foreign capital. ${ }^{62}$ The price is determined by the market supply and demand and has been that way since the industry was deregulated in 1985. The market is competitive with nearly 700 private natural gas producers. ${ }^{63}$

SC 1994, c 41; International Energy Agency, Energy Policies of IEA Countries: Canada 2015 Review (Paris: IEA, 2016) at 23 [IEA, Energy Policies].

Ibid at 23-24.

Jeff Christian \& Lana Shipley, "Electricity Regulation in Canada: Overview," Energy and Natural Resources Global Guide 2016/17 (Vancouver: Thomson Reuters, 2016).

Pete Evans, "Privatization of Canada's Electrical Grid Accelerating," CBC News (30 March 2011), online: $<$ https://www.cbc.ca/news/business/privatization-of-canada-s-electrical-grid-accelerating-1.101 $6930>$.

Ibid.

See Christian \& Shipley, supra note 57.

Ibid.

IEA, Energy Policies, supra note 55 at 117.

Ibid. 
Like electricity, the oil and renewable energy industries are governed primarily by provincial governments, notwithstanding the National Energy Board which is responsible, among other things, for regulating the oil and gas pipelines which fall under federal jurisdiction, including the pipelines which cross interprovincial and international borders. ${ }^{64}$ On 18 June 2015, the Pipeline Safety Act ${ }^{65}$ received Royal Assent; the Act seeks to ensure the safety of Canada's energy transportation and thus prevent spills, and to establish preparedness and response systems. ${ }^{66}$ To complement the Pipeline Safety Act, provinces, specifically Alberta, have adopted stringent greenhouse gas emissions regulations. ${ }^{67}$

Alberta oil sands (which produce the bulk of Canadian oil) are regulated by the Alberta Energy Regulator (AER) ${ }^{68}$ The AER is authorized to make decisions on applications for energy development projects and monitors them to ensure compliance. The AER, amongst other duties, engages with stakeholders, issues approvals for energy projects, and regulates closures, suspensions, and abandonments. ${ }^{69}$ Currently, the AER regulates over 170,000 operating wells, $431,000 \mathrm{~km}$ of pipelines, and 797 gas processing plants. Crown corporations and companies that are interested in initiating a new project must apply to the AER for approval. ${ }^{70}$ The AER plays an ongoing role in monitoring and ensuring that energy resource activities comply with all energy policies and applicable regulations.

The process of applying to the AER to initiate a project is extensive; first, a preapplication is submitted which requires the applicant to demonstrate that they have consulted appropriate stakeholders to ensure that the affected parties have had an opportunity to understand how the project might impact them. ${ }^{71}$ Where a stakeholder or Aboriginal group has concerns about a project, they can file a statement of concern to the AER that leads to a hearing. This process is followed by the application which requires the developer to submit information explaining both basic contact information and details of the project. ${ }^{72}$ A public notice is then issued by the AER, along with a decision and an opportunity to appeal. ${ }^{73}$

Where a private investor intends to invest in onshore oil owned by a provincial Crown, the investor must enter into a petroleum and natural gas licence, lease, or an oil sands lease. ${ }^{74}$ The Crown lease allows the investor to develop, explore, and produce the petroleum substances that are outlined in the lease agreement. Notably, the investor is required to comply with all applicable laws and regulations. Therefore, where the Crown alters

\section{$64 \quad$ Ibid at 136.}

65 SC 2015, c 21 .

66 IEA, Energy Policies, supra note 55 at 137.

Ibid at 138 .

68 Alberta Energy Regulator, "Who We Are," online: <https://www.aer.ca/providing-information/aboutthe-aer/who-we-are>.

69 Alberta Energy Regulator, "How Does the AER Regulate Energy Development in Alberta?" online: $<$ https://www.aer.ca/protecting-what-matters/holding-industry-accountable/how-does-the-AER-regulateenergy-development-in-alberta>.

Alberta Energy Regulator, "Who We Are," supra note 68.

Alberta Energy Regulator, "Draft Directive 023: Oil Sands Project Applications"'(Calgary: AER, 2013), online: $<$ https://www.aer.ca/documents/directives/DraftDirective023_20130528.pdf $>$.

Ibid.

Alberta Energy Regulator, “Application Processes,” online: <https:/www.aer.ca/regulating-develop ment/project-application/application-processes>.

Gowling WLG, "Guide to Doing Business in Canada: Oil \& Gas," Mondaq (23 November 2016), online: <www.mondaq.com/canada/x/546866/Oil+Gas+Electricity/Guide+To+Doing+Business+In+ Canada+Oil+Gas $>$. 
legislation, the lease agreement may be subject to change. ${ }^{75}$ Alberta oil sands are subject to separate regulatory regimes that require private investors to seek rights by way of a permit or an oil sands lease. A private investor must also obtain an exploration licence before conducting seismic activities. ${ }^{76}$

According to a 2012 Financial Post article, the majority of oil sands ownership and profits at the time were foreign. ${ }^{77}$ The article notes that "[m] ore than two-thirds of all oil sands production in Canada is owned by foreign entities." "78 However, in 2017, Petronas and other major oil and gas investors cancelled the Pacific NorthWest LNG export project. ${ }^{79}$ There have been several other high profile divestments in recent years by global majors in Canada's oil and gas sector, such that Canadian ownership of natural gas and oil production assets has increased significantly. ${ }^{80}$ This has largely been a result of international oil companies' "redeploying their capital to more profitable opportunities elsewhere. Canada's environmental and fiscal regimes, the high cost of labour and materials, difficulties in executing export projects and investors achieving quicker payback of invested capital elsewhere." 81

Finally, the legal framework of Canadian natural resources is unique as a result of the significant Aboriginal population. According to Canadian law, where conduct is contemplated that could adversely affect Aboriginal rights (for example, constructing a pipeline and new oil rigs), the Crown has a duty to consult with, and accommodate, where appropriate, the Aboriginal community (the AER is expressly excluded from assessing the adequacy of Crown consultation). ${ }^{82}$ The scope of such consultation depends on the degree of impact the activity will have on the associated Aboriginal rights. Consequently, the more impact the activity will have, the greater the consultation that is required and the more impact that the opinion of community will have on the project. A lack of adequate consultation can result in challenges to the decision, legal battles, and thus delays. ${ }^{83}$

\section{MEXICO}

\section{A. BACKGROUND OF OIL AND GAS INDUSTRY AND GENERAL InFormation OF CURRENT Market: Production}

Despite it being a relevant crude oil producer and the holder of massive reserves on a global scale, for decades Mexico remained closed to private investment. For more than 60 years, Mexico relied on a single operator, and a vertically integrated supply monopoly for

Canadian Association of Petroleum Producers, "An Introduction to Oil \& Gas Leasing in British Columbia, Alberta and Saskatchewan" (June 2014) at 4. Ibid at 7 .

"Majority of Oil Sands Ownership and Profits are Foreign, Says Analysis," Financial Post (10 May 2012), online: $<$ https://business.financialpost.com/news/majority-of-oil-sands-ownership-and-profitsare-foreign-says-analysis $>$.

Ibid.

Chrysten Perry \& Christopher Nixon, "Canadian Ownership in Domestic Oil and Gas Grows as Foreign Interest Wanes," The Lawyer's Daily (5 December 2017), online: <https://www.thelawyersdaily.ca/ articles/5340/canadian-ownership-in-domestic-oil-and-gas-grows-as-foreign-interest-wanes>.

Ibid.

Ibid.

IEA, Energy Policies, supra note 55 at 24.

See e.g. Haida Nation v British Columbia (Minister of Forests), 2004 SCC 73. 
its oil and gas industry - its national oil company, Petróleos Mexicanos, known as Pemex. Following the 1938 nationalization of oil and gas assets by President Lázaro Cárdenas, in 1958 the Regulatory Law of Constitutional Article 27 in the Field of Petroleum (Ley Reglamentaria del Articulo 27 Constitucional en el Ramo del Petróleo) (the 1958 Petroleum Law) expanded the legal monopoly to include all aspects, from oil and gas production, to all activities of refining, transportation, distribution, marketing, and sales of oil and gas, and all derivatives. The 1958 Petroleum Law was even subsequently amended to provide that, with respect to service contracts, consideration could not be linked to the results of production and would need to be solely in cash. ${ }^{84}$ In 1960 , this was elevated to constitutional level.

In the context of this monopoly, Pemex made significant discoveries in the late 1970s and early 1980s in offshore shallow waters in the Gulf of Mexico, namely the Cantarell field that would become the crown jewel, allowing Pemex to reach levels of production of $3.5 \mathrm{~m} \mathrm{~b} / \mathrm{d} .{ }^{85}$ Pemex redirected a significant portion of its efforts to such production, and drastically reduced focus on onshore production of smaller fields in several states along the Gulf coast.

With a federal budget relying on more than 40 percent of its revenues from crude oil production, the government controlled Pemex focused its investments largely in continuing to expand its shallow water production in Cantarell and surrounding fields until production peaked in 2004, when it started its inevitable and irreversible decline. ${ }^{86}$ Pemex had failed to undertake sufficient exploration to replace reserves (as had other oil and gas companies). Given the federal government's reliance on Pemex as the major cash generator for the budget, it spent every available dollar in operation, while neglecting to modernize midstream and downstream infrastructure, otherwise closed to the participation of other players.

In the context of NAFTA, Mexico negotiated a piecemeal opening of a very limited set of activities: midstream (transportation, distribution, and marketing) natural gas activities were liberalized, but with the rest of the market continuing to be monopolized, and with a natural gas sales market also continuing to be controlled by Pemex, projects developed by private players were mostly anchored by the government. At the same time, the second vertically integrated monopoly in the energy industry - electricity - was also maintained as closed, although a limited opening was introduced both in NAFTA and the Electric Energy Utility Law (Ley del Servicio Publico de Energia Electrica) by carving out limited activities that would not be considered as a public utility and thus open to private investment. This was the case for (1) so-called self-supply power plants, and (2) independent power producers, that is, plants developed by private producers anchored by long-term Power Purchase Agreements to supply solely Mexico’s vertically integrated monopoly, Comisión Federal de Electricidad (CFE) ${ }^{87}$ This opening, coupled with the need to transition to clean air laws under NAFTA, entailed the construction of dozens of combined cycle power, natural gas fueled power

84 See Diario Oficial de la Federación, "Ley Reglamentaria del Artículo 27 Constitucional en el Ramo del Petróleo" (29 November 1958), art 6o, online: <www.diputados.gob.mx/LeyesBiblio/abro/lrart27 rp/ LRArt27_RP_abro.pdf>.

85 See Daniel Romo, "The Cantarell Oil Field and the Mexican Economy" 46:183 Revista Latinoamericano de Economía, online: <https://probdes.iiec.unam.mx/en/revistas/v46n183/body/v46n183a6_1.php>. Ibid.

See Diario Oficial de la Federación, "Ley Del Servicio Público de Energía Eléctrica,” (22 December 1975), art 3o, online: <www.diputados.gob.mx/LeyesBiblio/abro/lspee/LSPEE_abro.pdf>. 
plants. Demand for natural gas also increased with the policy determination under clean air laws to convert from highly polluting fuel oil plants to natural gas.

Chapter 6 of NAFTA contemplated, as part of the trade provisions, several reservations by Mexico to guarantee the continuation of its vertically integrated monopolies in the oil and gas and electricity industries and, as part of that, a reservation to allow Pemex to also maintain the monopoly of imports of gasolines and other liquids. ${ }^{88}$ The exception was natural gas, which was opened to free importation by any party, and a scaled down duty mechanism. Steep increases in natural gas demand from combined cycle plants coming on line under the Independent Power Production program and through self-supply mechanisms found very limited response on the side of gas production, with Pemex unable, from a resource standpoint, to invest in increased gas production. At the same time, the shale gas revolution in the Permian Basin and Eagle Ford created a boom and a hike in production in the US which rapidly caused liquidity for gas sales availability to pour into the Mexican market through the South Texas market. ${ }^{89}$ Mexico coped with the demand by increasing natural gas transportation availability with the construction of new infrastructure (including a new 48 inch trunkline named Los Ramones) and a whole new system in the Northwest areas of the country where infrastructure was non-existent. ${ }^{90}$

The lack of a holistic approach to manage growth of a vertically integrated monopolized industry, which resulted in Pemex neglecting to invest in gas production, in refining, and in midstream and downstream infrastructure, created an industry full of contradictions where, in an oil and gas reserve rich country, Mexico is importing 78 percent of its natural gas needs, while only about 20 percent is domestically produced; more than 65 percent of the gasoline consumed in Mexico is imported due to limited and increasingly deteriorating refining capacity; gasoline storage infrastructure is very limited and strategic reserves are at a minimum, while natural gas storage infrastructure is non-existent. ${ }^{91}$ Because of the drastic decline of production from Cantarell and these critical set of real concerns created in 2011-2012, there is an expected consensus for the need to reshape, restructure, and open the energy industry.

Due to the sharp decline in Cantarell and its mega fields in shallow waters, Mexico's production platform has fallen now to $1.9 \mathrm{~m} \mathrm{~b} / \mathrm{d}$. A table detailing oil production in Mexico from 1994 to 2017 is available online. ${ }^{92}$ This data has been compiled into a graph to highlight Mexico's declining production in recent years. ${ }^{93}$ While efforts to multiply production capabilities with a multiplicity of operators are under way, as further discussed below, time for development is still required to correct the declining curve and eventually increase the production platform again.

NAFTA, supra note 1, Annex III, III-M-1.

US Energy Information Administration, "U.S. Natural Gas Exports and Re-Exports by Point of Exit" (2018), online: <https://www.eia.gov/dnav/ng/ng_move_poe2_dcu_NUS-NMX_a.htm>.

Secretaría de Energía, Prospectiva de Gas Natural 2017-2031 (Mexico City: SENER, 2017) at 54-56.

See online: $<$ www.pemex.com/ri/Publicaciones/Paginas/IndicadoresPetroleros.aspx $>$.

Secretaría de Energía, "Sistema de Información Energética," online: <sie.energia.gob.mx/>. Ibid. 


\section{B. ENERGY REFORM}

Although different from its NAFTA partners, which maintain a unique private ownership structure globally, like many other jurisdictions, Mexico has a state ownership principle with respect to hydrocarbons. Under the Mexican Constitution, all domestic hydrocarbons belong to the nation, which then, under the reform, entrusts their exploitation to a multiplicity of operators.

The 2014 reform, which constituted an overhaul of the Mexican legal framework, including amendments to the Mexican Constitution to lock in its foundations, was an overreaching, sweeping change for the whole industry, beyond international expectations, and included:

- The determination that exploration and production be done by designation of the upstream regulator (which although already existed in the past, was revamped) the National Hydrocarbons Commission (Comisión Nacional de Hidrocarburos) $(\mathrm{CNH})$ as the administrator of contracts and licences with the private operators;

- The liberalization of midstream and downstream activities, not only for gas, but also for liquids and all other products, including refining, processing, transportation, distribution, storage, marketing, and retail;

- The opening of international trade of products to all players, which was previously reserved to Pemex and its affiliates; and

- The liberalization of the electricity market, through (1) the creation of a wholesale electricity market, administered by an independent system operator called the National Center for Energy Control (CENACE), (2) the liberalization of power generation for sales to the market (merchant plants) or to qualified offtakers, and (3) international trade (imports and exports) of power. ${ }^{94}$

The reform created a major boost for investment in Mexico's energy sector. In 1994, foreign investment was limited to $\$ 10,646.9$ million. ${ }^{95}$ By 2017 , farmouts alone accounted for $\$ 9,255$ million of foreign investment capital. ${ }^{96}$ Further investment in shallow waters oil fields was

See Diario Oficial de la Federación, "Ley de la Industria Eléctrica” (11 August 2014), online: <www. dof.gob.mx/nota_detalle.php?codigo=5355986\&fecha=11/08/2014> [“Electrical Energy Low”]. Dirección General de Inversión Extranjera, "Inversión Extranjera Directa en México y en el Mundo: Carpeta de Información Estadística" (8 December 2017), online: < https://www.gob.mx/cms/uploads/ attachment/file/279079/Carpeta_IED.pdf>.

Comisión Nacional de Hidrocarburos, "Inversión Estimada de Contratos de Exploración y Extracción" (April 2018), online: $<$ https://portal.cnih.cnh.gob.mx/downloads/es_MX/estadisticas/Reporte\%20Invers iones\%20Rondas.pdf> [CNH, "Inversión"]. 
$\$ 3,800$ million, ${ }^{97}$ L2 onshore was $\$ 89$ million, ${ }^{98}$ and L3 onshore was $\$ 2,343$ million. ${ }^{99}$ Taken together, foreign investment in 2016 amounted to $\$ 40,856$ million. A second round of bidding over 2016-2017 resulted in foreign investment of an additional \$175 billion. ${ }^{100}$

\section{LEGAL FraMeWORK}

1. DOMESTIC REGULATORY FRAMEWORK: OWNERSHIP, REGIME EXPLORATION, AND PRODUCTION TRANSPORTATION COMMERCIALIZATION REFINING

The cornerstone of the energy reform was the amendment of Article 27 of Mexico's Constitution and an inclusion of certain transitional provisions, to adopt the following fundamental principles:

(1) Ownership of the hydrocarbons on site by the Mexican State;

(2) Exploitation either by Pemex or by private operators, through the contractual schemes that may be defined for such purposes;

(3) The opening of midstream and downstream to private parties; and

(4) The liberalization of the electricity market. ${ }^{101}$

A fundamental piece of the 2014 reform is the enactment of the new Hydrocarbons Law, which organizes the regulation of the oil and gas sector in a bifurcated manner:

- Upstream is regulated by the $\mathrm{CNH}$, who administers the bids and awards contracts and licences, and administers the operators throughout the life of the exploration and production projects, while

- Midstream regulation is entrusted to the Energy Regulatory Commission (Comisión Reguladora de Energía or CRE), including transportation, distribution, storage, marketing, and retail of both hydrocarbons and products. The Ministry of Energy (Secretaría de Energía or SENER), which maintains its principal role as policy maker and sector planner, maintained regulatory powers in respect of refining (including permitting new refineries and the Pemex existing refineries) and gas

Sergio Meana, "Coldwell Estima Inversiones por 3,800 mdd en Ronda 3.1," El Financiero (28 September 2017), online: <www.elfinanciero.com.mx/economia/coldwell-estima-inversiones-por-800mdd-en-ronda.html>.

Secretaría de Energía, Comisión Nacional de Hidrocarburos \& Secretaría de Hacienda y Crédito Público, "Boletín de Prensa No. 001" (24 January 2018), online: <https://rondasmexico.gob.mx/wp-content/ uploads/2018/01/BOLETIN_001 Ronda_3.2.pdf $>$.

$99 \quad$ Aldo Flores Quiroga, "Tercera Convocatoria de la Ronda 3 Burgos - Tamaulipas: Exploración y Extracción en Zonas Terrestres de Recursos no Convencionales" (March 2018), online: $<$ https://rondas mexico.gob.mx/wp-content/uploads/2018/03/02-SENER-20180301.pdf>.

Secretaría de Energía, "Con los Proyectos en Este Año las Inversiones Totales Comprometidas con la Reforma Energética Rebasarán los 200 Mil Millones de Dólares: PJC" (8 February 2018), online: $<$ https://www.gob.mx/sener/prensa/con-los-proyectos-a-realizar-en-este-ano-las-inversiones-totalescomprometidas-con-la-reforma-energetica-van-a-rebasar-los-200-mil-millones-de-dolares-pjc >.

101 See Constitución Politíca de los Estrados Unidos Mexicanos, art 27 [Constitución]. 
processing. Likewise, while international trade of hydrocarbons and products is opened by the reform, SENER maintains a regulatory role to approve the imports and exports, mainly in order to safeguard national energy security and supply. ${ }^{102}$

While the reform opened the sector to private operators, Pemex remained as the preponderant player, both on the upstream side and for the rest of activities. Given that the reform did not call for a divestiture of assets by Pemex, the national oil company maintained the assets that it previously had as a legal monopoly, including its refineries, a limited system of liquids transportation pipelines, and over 50 storage and distribution terminals. The natural gas transportation system was spun off to a separate government controlled entity, called the National Center for Control of Natural Gas (CENAGAS).

As noted earlier, the ownership of the hydrocarbons on site remains on the Mexican State. The Nation then entrusts the $\mathrm{CNH}$ with the task of awarding contracts to private operators (or entitlements to Pemex) to exploit the resources. Contracts may either be production sharing contracts, or licenses, and the Hydrocarbons Revenues Law (Ley de Ingresos sobre Hidrocarburos) sets up the structure for payment by the operators of the revenues deriving from hydrocarbons production, which in turn are autonomously administered by the Mexican Petroleum Fund (Fondo Mexicano del Petroleo), a trust guaranteed independence constitutionally to protect the use and destiny of the revenues stemming from hydrocarbons production.

Under the Hydrocarbons Law, the sale of the hydrocarbons pertaining to the state under the corresponding production sharing contracts and delivered by the operators, are sold through a trading company retained by the state for such purpose. This trading company will then conduct the international trade (exports and sales of crude) on behalf of the Mexican State in the international market.

\section{INTERNATIONAL FRAMEWORK}

\section{Trade And InVEStment Flows of OIL AND Gas Since 1994}

The trade integration of Mexico with the US and Canada since NAFTA has included its oil and gas industry. ${ }^{103}$ Since 1994 when NAFTA entered into force, Mexico, the US, and Canada have created an integrated and interdependent North American energy market despite the constitutional restrictions that were in place at that time in Mexico. With respect to trade flows, NAFTA has played a critical role by gradually eliminating tariffs which have resulted in more efficient energy markets.

Ley de Hidrocarburos (México), DOF 15-11-2016, online: <www.diputados.gob.mx/LeyesBiblio/pdf/ LHidro 151116.pdf $>$ [Hydrocarbons Law].

In general, Mexico was the second largest goods export market for the US in 2016. US goods exports to Mexico in 2017 were US\$243.3 billion. Mexico is currently the third largest goods trading partner to the US with US\$557.6 billion in total (two-way) goods trade during 2017. Also, Mexico was the second largest supplier of imported goods for the US in 2017. US goods imports from Mexico totalled US\$314.3 billion in 2017. See Office of the US Trade Representative, "Mexico" (2018), online: $<$ https://ustr.gov/countries-regions/Americas/mexico $>$. Canada and Mexico are each other's third largest trading partner, with two-way goods trade amounting to 43.3 billion in 2017. See Government of Canada, "Canada-Mexico Relations: A Strategic Partner for Canada" (May 2018), online: <www.canada international.gc.ca/mexico-mexique/canmex.aspx?lang=eng>. 
It is important to note that prior to the 2013-2014 energy reform and at the time NAFTA was implemented, imports and exports of crude oil and refining products were activities reserved to the government through a Pemex subsidiary. ${ }^{104}$

Moreover, in Mexico the supply of North American energy products has satisfied the demand of growing export industries such as the manufacturing sector. In addition, North American energy products, in particular gasolines and diesel, have complemented the supply of such fuels provided by Pemex during difficult times of high volatility in international oil prices. In fact, the US-Mexico energy trade is one of the areas where the US has a trade surplus. ${ }^{105}$

With respect to crude oil, Mexican exports of heavy crude oil to some US refineries have been very relevant to substitute for the lack of refining capacity for that type of oil in Mexico. In that respect, exports of heavy crude oil are returned (exported back from the US) to Mexico as gasolines and diesel after the refining process, creating an important supply chain of crude oil and fuels on both sides of the border. ${ }^{106}$

As a result of the recent volatility in oil prices, the decline of production in Mexico, and the development of unconventional resources in the US and Canada, integration will be essential. The energy reform in Mexico has resulted in a basis to create a more integrated oil and gas market in North America by growing the opportunities for more free trade and investment.

The liberalization of some legal restrictions in the areas of commercialization, transportation, and storage of oil and refining products, in particular gasoline, has facilitated trade of energy products. Accordingly, in order to satisfy the increasing demand of energy products, the participation of private parties in foreign trade activities, and the construction of common transportation and storage infrastructure across the US-Mexican border and at the most relevant ports of Mexico will be essential to strengthen international trade of energy products. A truly integrated North American energy market will require interconnectivity to move products and reduce logistic costs. has subsidiaries in different countries. PMI has acted as a trading company for Pemex in charge of its foreign trade activities. This trading structure is unique in the global oil and gas markets since PMI's subsidiaries are subject to the trade laws of different jurisdictions. See PMI Comercio Internacional, “¿Qué es PMI?”(2016), online: <www.pmi.com.mx/Paginas/Inicio.aspx>.

105 Since the so-called "shale revolution, U.S. energy commodities such as natural gas and gasoline have become a staple of the Mexican energy diet. In 2016, the value of U.S. energy exports (e.g., gasoline, diesel, natural gas) was more than twice the value of energy imports (primarily heavy crude oil) from Mexico (\$20.2 billion vs. US\$8.7 billion)" (Adrian Duhalt, "NAFTA Negotiations: What's In It for the U.S.-Mexico Energy Trade?" Forbes (17 November 2017), online: <https://www.forbes.com/ sites/thebakersinstitute/2017/11/17/nafta-negotiations-whats-in-it-for-the-u-s-mexico-energy-trade/ $>$ ).

106 The Pemex-Shell refinery at Deer Park, Texas, is one of the most relevant export-import projects between Mexico and the US. As of 2016, Mexico's exports of heavy crude oil to the Deer Park refinery amounted to 170,000 barrels per day (BPD); 136,000 BPD of gasoline and diesel export returns to Mexico, and 6 million gallons of deliveries of gasoline and diesel goes to the US market. See American Petroleum Institute, "Energy Benefits of NAFTA" (2017), online: <https:/www.api.org/ /media/Files/ Policy/Trade/Energy-Benefits-of-NAFTA.pdf $>$. The structure used by Pemex's subsidiary PMI is the customs regime of temporary exportation for elaboration, transformation, and repair provided by Article 117 of the Customs Law (Ley Aduanera) pub DO 15-12-1995. 


\section{Powers to Regulate Foreign TRADE - INTERNATIONAL TRADE AGREEMENTS (NAFTA)}

In Mexico, the regulation of foreign trade (also referred to more broadly as international trade) is a matter of federal law. Congress has the power to enact laws imposing tariffs on foreign trade and the Executive Branch has the power to issue regulations in order to implement foreign trade laws. ${ }^{107}$

Under Article 4 of the Foreign Trade Law, the Executive Branch has the following most relevant powers:

The Federal Executive Branch shall have the following powers:

I. Create, increase, reduce or eliminate tariffs, by means of decrees published in the Federal Register as provided by article 131 of the Mexican Constitution;

II. Regulate, restrict or prohibit the exportation, importation, or transit of goods, when deemed urgent, by means of decrees published in the Federal Register as provided by article 131 of the Mexican Constitution;

III. Establish measures in order to regulate or restrict exports or imports through administrative regulations issued by the Ministry of Economy;

IV Establish measures to regulate the transit of foreign goods;

V. Conduct the international trade negotiations through the Ministry of Economy. ${ }^{108}$

Furthermore, the President as Chief of the Executive Branch through the Secretary of Economy has the power to negotiate and execute international treaties, including economic or trade agreements, and the Mexican Senate has the power to approve and ratify them. ${ }^{109}$ The process for negotiating, reforming, and terminating international treaties in Mexico reflects a fair balance of powers, but as in any legislative process, it is not exempt from political interests.

In the area of trade, Mexico is part of the World Trade Organization (WTO), and has executed 12 Free Trade Agreements (FTAs) with 46 countries. ${ }^{110}$ Moreover, Mexico is one of the countries that has negotiated the now called Comprehensive and Progressive

See Constitución, supra note 101, arts 73,76,89,131. The most important federal statutes regulating foreign trade are: (i) the Foreign Trade Law and its Regulation (Ley de Comercio Exterior) pub DO 2707-1993; and (ii) the Customs Law and its Regulation (Reglamento de la Ley Advanera). Ley de Comercio Exterior, ibid, art 4. de Tratados) pub DO 02-01-1992; Law for the Approval of International Economic Treaties (Ley Sobre la Aprobación de Tratados Internacionales en Materia Económica) pub DO 02-09-2004.

110 See Secretaría de Economía, "Negociaciones Comerciales Internacionales," online: <www.2006-2012. economia.gob.mx/comunidad-negocios/comercio-exterior/tlc-acuerdos $>$. 
Agreement for Trans-Pacific Partnership Agreement (TPP) which is pending signature and final ratification. ${ }^{11}$

On the other hand, in the area of oil and gas, Mexico is part of the IEA and it is an independent oil producer not part of the Organization of Petroleum Exporting Countries (OPEC). In Mexico, FTAs are self-executing international treaties that do not require implementing legislation. Once a trade agreement is approved by the Mexican Senate, it enters into force and becomes the law of the land as provided by Article 133 of the Mexican Constitution. Nevertheless, the execution of FTAs normally requires amendments or reforms to existing domestic legislation in order to avoid conflict of laws.

In 1994 when NAFTA was executed, Mexico had to amend several different federal laws and statutes in order to adjust the domestic legal framework to the provisions of the different chapters of NAFTA. In some cases, the Congress enacted new laws in particular areas such as foreign investment, foreign trade practices, and financial services. ${ }^{12}$

Twenty-four years later, it is fair to say that the current NAFTA 2.0 negotiations will be a test to evaluate the efficiency of the current process for negotiating FTAs in a year when Mexico will have elections for renewing both the Executive Branch and the Congress.

It is important to note that the oil and gas industry in Mexico has always been a very sensitive area and part of the political and economic debate of the country. For decades, the development of the oil and gas industry has represented the cornerstone of the nationalistic economic model followed in Mexico since the 1938 expropriation of the oil industry. The central principle is that the ownership of all hydrocarbons belongs to the nation and the development of the oil industry shall benefit the people. The state has the obligation to develop the industry in order to protect the national interest.

In this context, Mexico negotiated the Energy and Basic Petrochemical Chapter 6 of NAFTA and within the framework of the constitutional restrictions in place in 1993-1994. The inclusion of this Chapter in the negotiations was perhaps the most difficult area at that time, but a very relevant step to establish the basis for a future North American energy market and perhaps the precedent for the 2013-2014 energy reform. Twenty-four years later, the reality is that the oil and gas sector is not one of the areas of controversy within NAFTA 2.0 negotiations, despite the political season in Mexico.

The original NAFTA Energy Chapter 6 is based on three important principles: (1) a full respect for the constitutional restrictions of each party; (2) the need to strengthen and increase trade of energy products and services by a gradual and sustained liberalization; and

111 The TPP has been one of the most successful trade negotiations of Mexico. It will be essential for diversifying Mexican exports. For more information on the TPP's negotiation, see ibid.

112 One of the most relevant laws enacted as a result of the execution of NAFTA was the Foreign Investment Law (Ley de Inversión Extranjera) pub DO 27-12-1993 [Foreign Investment Law]. In fact, this law was enacted before NAFTA was actually signed in 1994 but just months after the negotiations of the final text were almost concluded in 1993. This law regulated the sectorial liberalization that opened foreign investment participation in different economic sectors of the Mexican economy under the principles agreed to in Chapter 11 of NAFTA, supra note 1. 
(3) the need to create competitive energy sectors. ${ }^{113}$ The express incorporation of the "constitutional full respect" principle was perhaps one of the turning points for the success of the 1993 NAFTA negotiations in Mexico.

Under Chapter 6 of NAFTA, the parties agreed to specific provisions with respect to: (1) import and export restrictions; (2) export taxes and other export related measures; (3) regulatory energy measures; and (4) national security measures.

Based on the constitutional restrictions in place during the original NAFTA negotiations, Mexico negotiated specific reserves applicable to the oil and gas industry that were incorporated in Annex 602.3 as follows:

1. The Mexican State reserves to itself the following strategic activities, including investment in such activities and the provision of services in such activities:

a) exploration and exploitation of crude oil and natural gas; refining or processing of crude oil and natural gas; and production of artificial gas, basic petrochemicals and their feedstocks and pipelines;

b) foreign trade; transportation, storage and distribution, up to and including the first hand sales of the following goods:

(i) crude oil,

(ii) natural and artificial gas,

(iii) goods covered by this Chapter obtained from the refining or processing of crude oil and natural gas, and

(iv) basic petrochemicals. ${ }^{114}$

As a result of the 2013-2014 energy reform most of the activities reserved under Annex 602.3 have been liberalized and are now open to private participation, in particular, import and exports of oil, gas, gasolines, and diesel.

While it is not the purpose of this article to speculate on the outcome of the current NAFTA 2.0 negotiations, it is clear that the discussions with respect to the oil and gas industry need to update the provisions of Chapter 6 to make them consistent with the new domestic legal framework that regulates the industry. ${ }^{115}$

In our view, the final goal for Mexico has to be the incorporation of specific provisions that may result in a truly integrated North American energy market. These provisions need to include common export and import measures and common binding criteria to impose trade barriers to the free access of energy goods to NAFTA markets. In addition, certainty and

115 See Secretaría de Economía, "Informe al Senado Sobre el Inicio de Negociaciones Para Modernizar el Tratado de Libre Comercio de América del Norte" (July 2017), online: <www.senado.gob.mx comisiones/desarrrolo_rural/docs/tlcan/informeAlSenado.pdf $>$. 
reciprocity are essential to achieving an integrated market now that Mexico has perhaps a more open oil and gas market than its two NAFTA partners. ${ }^{116}$

Other specific areas of NAFTA that are relevant for the oil and gas sector are investor-state disputes and protection of investments which are essential for the success of the new investments in this sector. ${ }^{117}$

\section{E. ForeIgn TrAde ACTIVITIES: IMPORTS AND EXPORTS}

In Mexico, the importation and exportation of petroleum, natural gas, and petroleum products $^{118}$ are now free activities that can be carried out by private parties subject to the requirements provided by the Hydrocarbons Law.

For purposes of this section and the other relevant foreign trade sections of this article with respect to Mexico, we will also refer to petroleum as oil or crude oil, and petroleum products as basically gasoline and diesel (and jointly as energy products) since these are the commercial terms used for these products in the global trade markets of energy commodities.

Under Article 2 of the Hydrocarbons Law, import and export activities of energy products (foreign trade) are not expressly included as one of the activities within Mexican territory regulated as the subject matter of that law. This exclusion does not mean that foreign trade activities of energy products are not covered by the provisions of the Hydrocarbons Law, but simply that these activities are regulated by the specific legislation applicable to foreign trade in general, subject to the special rules of a particular title of the Hydrocarbons Law. ${ }^{119}$

Under Article 48 (I) of the Hydrocarbons Law, the importation and exportation of oil, natural gas, gasoline, and diesel can be carried out by private parties through a permit issued by the Ministry of Energy. Legally, these permits are non-tariff regulations since they have to be complied with at the point of entry or departure (at the time of the importation or exportation).

In order to implement the procedure for granting import or export permits, the Ministries of Energy and Economy issued a specific Decree establishing the tariff classification of the

116 Perhaps one of the areas that remains restricted to foreign investment is coastal navigation or cabotage (navegación de cabotaje). This is a critical area for the full success of the offshore upstream projects in Mexico since they will be mostly developed by international companies, in particular from the US and Canada. Reciprocity will be essential in this area, since the US "Jones Act" also restricts majority foreign investment participation in coastal navigation. See Foreign Investment Law, supra note 112, art $7(\mathrm{v})$.

117 Mexico is now part of the International Convention for Settlement of Investment Disputes (ICSID) which helps to provide certainty for large economic investments that are flowing to Mexico in exploration and production activities. Ratification by the Senate is pending as of writing.

118 The term petroleum is defined as the mixture or blending of hydrocarbons that exists in liquid phase in the fields and remains as such under original conditions of pressure and temperature. It can include small amounts of substances that are not hydrocarbons. Natural gas is the mixture or blending of gases obtained from the extraction or the industrial processing and which is primarily constituted by methane. Petroliferous are defined as products that are obtained from the refining of petroleum or from the processing of natural gas and which are directly derived from hydrocarbons, such as gasolines, diesel, kerosene, fuel oil, and liquefied petroleum gas. See Hydrocarbons Law, supra note 102, art 4.

Title III of the Hydrocarbons Law referred to as Other Activities of the Hydrocarbons Industry (De las demás Actividades de la Industria de los Hidrocarburos) covers the exportation and importation of oil, natural gas, gasoline, and diesel. See ibid, Title III. 
energy products eligible for such permits (Hydrocarbons Trade Decree). ${ }^{120}$ Under the Hydrocarbons Trade Decree, tariff codes 2709.001 (crude oil); 2710.11 .04 (gasoline); 2710.19.05 (fuel oil); 2710.19.04 (diesel); and 2711.12.01 (propane) all require a prior import permit. ${ }^{121}$ In the case of exports, gasolines, fuel oil, liquefied natural gas, diesel, and propane all require prior export permits. ${ }^{122}$

\section{F. CURRENT TRENDS AND INVESTMENT OPPORTUNITIES}

\section{UPSTREAM: ROUNDS}

With the 2014 energy reform, Pemex was granted through the so-called "Round Zero" all the fields it was then producing, and a portion (about two thirds) of those in which it was undergoing exploratory works prior to the reform. The rest of the reservoirs and fields in the country (about 69 percent of prospective reserves) were released for administration by the $\mathrm{CNH}$ on behalf of the Mexican State. ${ }^{123}$

As of this date, the $\mathrm{CNH}$ has successfully undertaken two bidding rounds and a third round of bids is currently undergoing. ${ }^{124}$ These rounds will offer reserves on the contractual areas, which are estimated to be 9,160,722 million barrels of equivalent oil. As a result, the $\mathrm{CNH}$ has entered into 74 exploration and production agreements, 49 for onshore, 16 for shallow waters, and nine for deep water. ${ }^{125}$

In addition to the foregoing, the $\mathrm{CNH}$ has been entrusted with organizing bids to obtain a partner for Pemex for farmouts which by statute should be awarded on the basis of a competitive tender. So far, the $\mathrm{CNH}$ has awarded the contractual areas of Trion, CárdenasMora, and Ogarrio. ${ }^{126}$ As of April 2018, the CNH estimated that the total investment for these rounds would sum to around US\$161,263 million. ${ }^{127}$

\section{Midstream: StORAGE LiQUids TERMinAls/PiPELINES}

In a country with a vertically integrated monopoly where storage and transportation of liquids was banned for private developers, and Pemex did not invest actively in its expansion, the sector presents material opportunities for growth and improvement of infrastructure.

See Diario Oficial de la Federación, “Acuerdo por el que Establece la Clasificación y Codificación de Hidrocarburos y Petrolíferos cuya Importación y Exportación Está Sujeta a Permiso Previo por Parte de la Secretaria de Energía" (29 December 2014), online: <dof.gob.mx/nota_detalle.php?codigo=537 $7567 \&$ fecha $=29 / 12 / 2014>$.

See General Import and Export Taxes Law (Ley de los Impuestos Generales de Importación y de Exportación) pub DO 18-06-2007. Ibid.

See Secretaría de Energía, "Ronda Cero,” online: <https://www.gob.mx/cms/uploads/attachment/file/ 55590/Ficha_tecnica_R0.pdf $>$.

See Comisíō Nacional de Hidrocarburos, "Estadísticas de Petróleo y Gas" (2 August 2018), online: $<$ https://portal.cnih.cnh.gob.mx/estadisticas.php>.

Comisión Nacional de Hidrocarburos, "Cifras Relevantes" (16 January 2018), online: < https://rondas mexico.gob.mx/wp-content/uploads/2018/01/CifrasRelevantes 20180116.pdf>.

Kathrine Schmidt, "Dea Makes Splash at Ogarrio," Upstream (4 Ōctober 2017), online: <www.upstream online.com/live/1357807/dea-makes-splash-at-ogarrio>.

CNH, "Inversión," supra note 96. 
One of the areas that is currently attracting the attention of foreign companies is the investment in facilities for the storage of crude oil and liquids.

As previously noted, interconnectivity and the development of common infrastructure are essential for an integrated North American energy market. As an example of this common infrastructure, we can currently note the projects to develop port terminals for the handling of oil, gasolines, diesels, and propane which are currently attracting the attention of foreign investors. $^{128}$

Port terminals for the handling of petroleum products (Oil Port Terminals) will be essential in Mexico in order to facilitate the logistics of expected trade flows as a result of energy reform.

Under the Ports Law, foreign investors can participate in the development and operation of Oil Port Terminals either directly or by partnering with current port operators. ${ }^{129}$ Mexican ports have the obligation to give priority to the development of Oil Port Terminals in the available port areas, as provided by recently enacted regulations. ${ }^{130}$

On the east coast, the most important ports with the capacity to develop Oil Port Terminals are the port of Altamira, the port of Tuxpan, and the port of Veracruz. In the case of the Pacific coast, the ports of Manzanillo, Lázaro Cárdenas, and Topolobambo are the most important ports.

The liberalization of imports of products by parties other than Pemex also creates a material pressure for the expansion of storage and transportation capacity in all areas of the country, especially while Pemex, as a preponderant player in the market, is subject to a special regulatory asymmetric regime to provide open access to its infrastructure through open seasons regulated by the CRE.

\section{GASOLINE RETAIL}

Perhaps the most readily available sign of the vertical monopoly prior to the 2014 reform to the general public was the non-existence of any gasoline service stations that were not Pemex franchises. The sweeping reform, including the liberalization of gasoline imports and retail to private players, quickly led to a situation where more than 20 percent of the gasoline stations in the country now operate with a brand other than Pemex. ${ }^{131}$ February 2017), online: <www.cre.gob.mx/documento/PresentacionCREJSL09_02_17.pdf > . See Ports Law (Ley de Puertos) pub DO 19-07-1993, art 10.

130 See General Port Rules (Reglas de Carácter General en Materia Portuaria) pub DO 22-11-2016, Title 4.

131 Arturo Solís, "Las 10 Marcas Nuevas con Más Gasolineras en México," Forbes México (28 March 2018), online: $<$ https://www.forbes.com.mx/las-10-marcas-nuevas-con-mas-gasolineras-en-mexico/>. 


\section{G. ELECTRICITY}

\section{LEGAL FRAMEWORK}

As sweeping as its oil and gas opening, Mexico completely restructured its electricity sector as part of the 2014 reform. The adoption of the Law of the Electricity Industry entails: the ability for private players to generate electricity for sale to other private players, or as a merchant plant to the electricity market; the creation of a wholesale electricity market (WEM) operated by an independent system operator, acquiring electricity and power from the generators and other suppliers; qualified users (consumers of more than one MW) are able to purchase power in the WEM or from qualified suppliers; the ability to import and export power for the market; and the creation of a market of clean energy certificates, linked to the obligation to consume clean energy and the incentives for clean energy producers stemming from the issuance of the clean energy certificates. ${ }^{132}$

\section{TRENDS AND OPPORTUNITIES}

Mexico has been seeing a major boost in the construction of renewable energy sources fueled, on the one hand, by the reduction in production costs as a result of technology evolution, and on the other hand, by the obligation on qualified users to consume energy so that Mexico can meet its obligations under the Paris Accord. In the last five years, wind power installed capacity has increased by more than 300 percent, while installation of solar power has also been flourishing. ${ }^{133}$ By 2024, Mexico plans to be generating at least 35 percent from clean energy sources. ${ }^{134}$

During the last two years, CENACE undertook auctions for long-term commitments on electricity and power from clean energy sources, and secured projects for more than 7,000 MW to be built by 2020 , constituting close to 10 percent of the national installed capacity. ${ }^{135}$ The investment expected for these projects will exceed US $\$ 8.5$ billion and entail significant international trade as well as investment in fixed assets and equipment. ${ }^{136}$

Transmission infrastructure continues to be built, including large scale transmission lines to connect the Baja Peninsula and Central Mexico through long-term service contracts for the financing and operation of the infrastructure, enhancing the transmission capabilities and availability to permit additional projects around the country.

As the WEM evolves and the qualified users become more sophisticated at acquiring power from different sources of supply, the market will continue to create opportunities for investment and trade, and be a significant piece of the puzzle for a more integrated North American energy market.

See "Electrical Industry Low," supra note 94.

Carlos Sáchez, "Infrastructure for Wind Energy in Mexico Grew 300\% Since 2012," Energy News (3 May 2018), online: <https://www.energynews.es/en/infraestructure-wind-energy-grew-mexico/>. Ibid.

Ibid.

Ibid. 


\section{UNITED STATES}

The North American energy market has a long, deep-rooted history, with the first recorded international electricity interconnection crossing the US-Canada border near Niagara Falls in 1901, ${ }^{137}$ and power lines sending electricity across the border between Texas and Mexico in the early 1900s. ${ }^{138}$ The implementation of NAFTA in 1994 allowed the three signatory countries to modernize energy policies, whereby the US and Canada committed to zero tariffs and open market access for a range of energy products. ${ }^{139}$ Mexico did not open its market to the same degree. Thus, certain prohibitions on imports and exports that apply to the US and Canada did not apply to Mexico. Consequently, the US-Canadian energy market has become much more integrated than the US-Mexican energy market. ${ }^{140}$

Since NAFTA was implemented, both Canada and Mexico have become crucial energy trading partners due to their proximity, reliability, and security. ${ }^{141}$ The US's largest energy trading partner is Canada, with US\$140 billion worth of energy trade in 2013, while the US trade with Mexico is smaller, worth US\$65 billion in 2012. ${ }^{142}$ The North American Cooperation on Energy Information created a map demonstrating the integrated energy trade between the three NAFTA signatories; this map can be found online. ${ }^{143}$

The US has long imported hydroelectric power from Canada. ${ }^{144}$ As a result of the ever growing interconnections in the North American energy industry due to NAFTA, ${ }^{145}$ all three signatories now trade "oil, refined fuels and natural gas back and forth across the northern and southern U.S. borders on a daily basis." ${ }^{146}$ The US has become a net exporter of refined products. $^{147}$

According to the US Department of Energy, the energy landscape has been changing over the decade due to:

- Developments in energy production, processing, and consumption;

- $\quad$ Fall in demand for US electricity; and

United States Department of Energy, Quadrennial Energy Review: Energy Transmission, Storage, and Distribution Infrastructure (Washington: DOE, April 2015) at 6-3, online: <https://www.hsdl.org/? abstract\&did=764791 > [DOE, Quadrennial Energy Report].

Patti Domm, "North American Trade is Powerful in Energy Despite Uncertainty of NAFTA," CNBC (8 March 2017), online: <https://www.cnbc.com/2017/03/06/north-american-trade-powerful-in-energydespite-uncertainty-of-nafta.html $>$ [Domm, "Powerful in Energy"].

139 David L Goldwyn, "How Can a Modernized NAFTA Revolutionize North American Energy?" (7 September 2017) at 2, online: <publications.atlanticcouncil.org/spotlight-nafta/>.

140 DOE, Quadrennial Energy Report, supra note 137 at 6-3.

141 Ibid at 6-2.

142 Ibid at S-22.

143 US Chamber of Commerce Global Energy Institute, "The Impacts and Future of North American Energy Trade" (13 December 2017), online: <https://docs.house.gov/meetings/IF/IF03/20171213/106729/ HHRG-115-IF03-Wstate-HarbertK-20171213.pdf> [GEI, "Impacts and Future"].

144 Domm, "Powerful in Energy," supra note 138.

145 Patti Domm, "One Industry Will Keep Holding North America Together, No Matter What Happens with Trump and Trade," CNBC (13 December 2016), online: <https://www.cnbc.com/2016/12/13/oneindustry-will-keep-holding-north-america-together-no-matter-what-happens-to-nafta.html $>[$ Domm, "One Industry"].

Domm, "One Industry," supra note 145. 
- Clean energy policies to reduce greenhouse emissions from the energy sector. ${ }^{148}$

These changes present opportunities for increased integration among the three NAFTA signatories. ${ }^{149}$

\section{A. BACKGROUND OF OIL AND GAS INDUSTRY AND GENERAL INFORMATION OF CURRENT MARKET For OIL AND Gas Production}

US onshore oil field development almost came to a halt by 2000 due to low oil prices, while drilling of vertical wells for natural gas and development of coalbed methane continued due to relatively strong natural gas prices. Unconventional methods of drilling, such as complex hydraulic fracturing, also known as "fracking," took off in the early 2000s in what the industry refers to as the "shale boom." 150 US natural gas production has grown from $45 \mathrm{Bcf} / \mathrm{d}$ in 1985 to nearly $75 \mathrm{Bcf} / \mathrm{d}$ in $2015 .^{151}$ In January 2017, "U.S. exports of natural gas to Mexico exceeded 4 billion cubic feet/day $(\mathrm{Bcf} / \mathrm{d})$ and is expected to double in the next few years."

With the 2008 financial crisis, oil and natural gas prices collapsed. Oil prices were able to recover quickly, which led the industry to search for new opportunities. New technologies enabled and strong oil prices encouraged the industry to explore and develop deep water and deep formation areas offshore, such as the Gulf of Mexico. ${ }^{153}$

In recent years, US petroleum has entered a "renaissance" period, whereby domestic crude oil production rose from $5 \mathrm{~m} \mathrm{~b} / \mathrm{d}$ in 2008 to over $9.5 \mathrm{~m} \mathrm{~b} / \mathrm{d}$ by mid-2015. ${ }^{154}$ Oil prices collapsed again in 2014 causing the industry to reduce offshore capital costs. Nonetheless, because offshore development and budgeting is much more long-term than conventional plays, the changes in offshore activity will not be notable, unless prices do not recover for a prolonged period of time. ${ }^{155}$ Although domestic production decreased by nearly $1 \mathrm{~m} \mathrm{~b} / \mathrm{d}$ when oil prices collapsed, output is once again increasing as world oil prices are recovering. ${ }^{156}$

\section{TRADE AND INVESTMENT FLOWS IN OIL AND GAS SINCE 1994}

NAFTA has allowed for an open southern border for natural gas. This, "combined with pipeline development and power generation in Mexico is providing an important and

DOE, Quadrennial Energy Report, supra note 137 at 6-3. Ibid.

US Energy Information Administration, Trends in US Oil and Natural Gas Upstream Costs (Washington: EIA, March 2016) at 3, online: <https://www.eia.gov/analysis/studies/drilling/pdf/up stream.pdf $>$ [EIA, Trends in US Oil].

Lucian Pugliaresi, "Integrating North American Trade Remains Essential for Economic Growth and Energy Security" (February 2017) at 1, online: <eprinc.org/wp-content/uploads/2017/02/new-Op-Ed-onNorth-America-Production-Feb-2017-1.pdf $>$.

Ibid at 2 .

EIA, Trends in US Oil, supra note 150 at 4.

Pugliaresi, supra note 151 at 1 .

Trends in US Oil, supra note 150 at 4.

Pugliaresi, supra note 151 at 1 . 
growing market for U.S. natural gas producers, pipeline developers, and equipment manufacturers." 157 Since 2009, gas pipeline exports to Mexico from the US have doubled. From the current 6 to 7 billion cubic feet capacity, US-Mexico cross-border capacity is expected to double by $2020 .^{158}$

The US is the largest purchaser of Canadian crude oil, importing $3.2 \mathrm{~m} \mathrm{~b} / \mathrm{d}$ of the $3.8 \mathrm{~m} \mathrm{~b} / \mathrm{d}$ Canada exported in 2016. The Canadian Association of Petroleum Producers expects Canadian production to increase to $4.9 \mathrm{~m}$ b/d by $2030 .{ }^{159}$

The Energy Information Administration (EIA) produced a chart that demonstrates the sources of energy the US has consumed since 1950, showing approximately 40 percent has come from petroleum. ${ }^{160}$ Additionally, the transportation sector has relied almost exclusively on petroleum, mostly gasoline, since $1950 .{ }^{161}$ Also note that fossil fuels decreased from comprising 86 percent of the primary energy use in 1990 to 82 percent in $2013 .{ }^{162}$

Finally, there is a significant planned expansion of pipeline capacity, creating increased trade and investment opportunities in pipelines for the US with both Canada and Mexico.

\section{B. LEGAL FRAMEWORK}

\section{OWNERSHIP REGIME}

The oil and gas ownership rights in the US differ from most international jurisdictions. In most international jurisdictions, oil and gas resources are state owned. ${ }^{163}$ In the US, oil and gas resources are generally privately owned.

Mineral interests, such as oil and gas, are owned by individuals, corporations, trusts, Native American tribes, or governmental entities that own the surface of the land. "Unless explicitly severed by deed or other instrument, oil and gas rights are owned by the surface landowner." 164 Landowners own and control not only the surface of the land, but also the right to access that land, as well as the rights to "explore for, drill, develop, produce and sell the oil and gas underlying their property." 165 Landowners can also lease or sell their oil and gas development rights, or choose to abstain from using their mineral rights. ${ }^{166}$

\footnotetext{
Ibid.

Domm, "Powerful in Energy," supra note 138.

Domm, "One Industry," supra note 145.

US Energy Information Administration, Monthly Energy Review (Washington: EIA, April 2014) at 7, online: <https://www.eia.gov/totalenergy/data/monthly/archive/00351404.pdf>.

Michael Ratner \& Carol Glover, "US Energy: Overview and Key Statistics" (27 June 2014) at 6, online: Federation of American Scientists <https://fas.org/sgp/crs/misc/R40187.pdf>.

Peter A O'Connor \& Cutler J Cleveland, “US Energy Transitions 1780-2010” (2014) 7:12 Energies 7955 at 7955.

Kirstin E Gibbs et al, "Oil and Gas Exploration and Production Laws in the USA," Lexology (6 July 2018), online: <https://www.lexology.com/library/detail.aspx?g=d768b461-0f6a-45ba-b306-9faflfff $35 \mathrm{~d} 5>$.

164 Michael P Joy \& Sashe D Dimitroff, “Oil and Gas Regulation in the US: Overview,” Practical Law (1 June 2016), online: <https://content.next.westlaw.com/Document/I466099551c9011e38578f7ccc38 dcbee/View/FullText.html $>$. 
When the landowner is a government entity, whether local, state, or federal, that government entity manages the oil and gas rights for the "public benefit."167 "On certain historical American Indian lands, oil and gas rights are owned or operated by the federal government on behalf of, or for the benefit of, certain American Indian individuals or tribal authorities." 168 Except for Texas and Florida, which own oil and gas rights up to three marine leagues from the coastline, states own oil and gas rights "to any submerged lands up to three nautical miles from their coastlines." ${ }^{169}$ Beyond the applicable three marine leagues or nautical miles, the federal government owns the oil and gas rights. ${ }^{170}$

Unlike jurisdictions where the government owns the land, the US "market structure for developing oil and gas resources is driven largely by private contracts rather than government regulation": ${ }^{171}$

\footnotetext{
Oil and gas development rights in the US are typically conveyed by private contracts such as a lease (between the owner of the minerals and the entity that will explore for oil and gas and/or develop it) or a joint operating agreement (a separate contract between the exploration company and other working interest owners). Leases can be granted by the actual owner of the oil and/or gas rights, whether it's an individual, a corporation, a Native American tribe, or a local, state or federal government owner, to the operating entity. Leases to privately held oil and gas rights are typically subject to private and confidential negotiation. Public land leases are typically conveyed based on a public and competitive bidding process, and awarded to demonstrably responsible entities on the basis of the highest and best terms offered for the property. Oil and gas lessess can, and often do, convey development rights among themselves by sale, swap, farm-out or joint development agreements. Oil and gas leases are generally considered as hybrid instruments in real property and contract, and are generally alienable unless limited by private contract. ${ }^{172}$
}

Oil and gas leases in the US are usually either in the form of a term of years during which the lessee can explore and develop for oil and gas without paying royalties, or for an indefinite term whereby the lease will continue as long as oil or gas is produced in a sufficient enough quantity to produce royalties. ${ }^{173}$

\section{REGULATORY FRAMEWORK}

Below is a list of key federal oil and gas regulations in the US: ${ }^{174}$

- $\quad$ The Mineral Leasing Act of 1920 - governs upstream activities on federal onshore property; ${ }^{175}$

174 Robert A James \& Stella Pulman, "United States" in Bob Palmer, ed, Getting the Deal Through: Oil Regulation 2015 (London, UK: Law Business Research, 2015) 192 at 193, online: <https://www. 
- $\quad$ The Mineral Leasing Act for Acquired Lands of 1947 - governs upstream activities on federal onshore property; ${ }^{176}$

- $\quad$ The Outer Continental Shelf Lands Act of 1953 - governs development of federal offshore property; ${ }^{177}$

- $\quad$ The Emergency Petroleum Allocation Act of 1973 - controls petroleum prices; ${ }^{178}$

- $\quad$ The Energy Policy and Conservation Act of 1975 (EPCA) - governs energy production and supply; ${ }^{179}$

- $\quad$ The Oil and Gas Royalty Management Act of 1982 - governs lease and royalty agreements; ${ }^{180}$

- $\quad$ The Petroleum Marketing Practices Act of 1978, amended in 1994 - governs supply agreements and leases held by retailers and wholesalers of trademarked motor fuels. ${ }^{181}$

Notably, in response to the 1973 oil crisis, the EPCA banned the export of domestically produced crude oil. The US Department of Commerce granted some exceptions, allowing 50 million to 100 million barrels to be exported annually. On 18 December 2015, during the global oil price crash, the US Congress lifted the crude oil export ban, allowing US oil producers to sell in global oil markets once again. ${ }^{182}$

In addition to the federal regulations, there are also state laws that govern exploration and production on private and state owned land. ${ }^{183}$

\section{INTERNATIONAL TRADE AGREEMENTS AND NAFTA'S CHAPTER 6}

The predecessor bilateral free trade agreement to NAFTA with Canada, the CUSFTA, contained provisions pertaining to the energy sector in its Chapter 9. NAFTA's energy provisions, contained in Chapter 6 titled "Energy and Basic Petrochemicals" (Articles 601 through 609), mirror CUSFTA's Chapter 9, but expand the geographical reach of the provisions to the entire North American Hemisphere, since CUSFTA did not encompass Mexico, and provide for more integration of the signatory markets. ${ }^{184}$ NAFTA is codified into US law pursuant to 19 USC $\$ 3311$.

30 USC $\$ 351$.

43 USC $\$ \$ 1331$.

Pub L No 93-159, 87 Stat 627.

Pub L No 94-163, 89 Stat 871.

30 USC \& 1701.

Pub L No 95-297, 92 Stat 322.

Joy \& Dimitroff, supra note 164.

James \& Pulman, supra note 174 at 193.

Roberto Rios Herrán \& Pietro Poretti, "Energy Trade and Investment Under the North American Free Trade Agreement" in Yulia Selivanova, ed, Regulation of Energy in International Trade Law: WTO, NAFTA, and Energy Charter (Alphen aan den Rijn, The Netherlands: Kluwer Law International, 2011) 335 at 339 . 


\section{CURRENT TRENDS AND INVESTMENT OPPORTUNITIES}

\section{UPSTREAM: EXPLORATION AND PRODUCTION}

Due to the shale boom and new technologies to extract shale gas and oil, the US "has undergone a remarkable transformation in energy terms over the past 10 years." "185 The shale boom "has brought tremendous economic benefits to communities across the United States." "186 IHS Energy's Cambridge Energy Research Associates predicts that 2.9 million jobs will result from the shale boom, that $\$ 113$ billion (in constant 2012 US dollars) will be created, and that every state in the US will benefit from it, whether there is shale development in that state or not. ${ }^{187}$

According to the IEA,

[t]he US is poised to become the world's largest oil producer in $2019 \ldots$ with stellar output from shale fields offsetting robust demand growth and supply cuts by other producers. US crude output, which is up $1.3 \mathrm{~m}$ barrels a day compared to last year, will soon pass Saudi Arabia and could overtake Russia by the end of the year to become "the global leader."

The US Energy Information Administration's Reference case ${ }^{189}$ prediction model shows a notable increase in natural gas production between from about 28 quadrillion BTU in 2017 to 45 quadrillion BTU in $2050 .{ }^{190}$

The oil industry expects the Trump administration to be a strong ally. The Trump administration's Energy Secretary, previously Texas Governor, Rick Perry, was on the board of Energy Transfer Partners, which is building pipelines to transport natural gas from the US to Mexico. ${ }^{191}$

\section{Midstream: StORAGE LiQUids TeRMinAls/PiPELINES}

The shale boom has also created an "unprecedented demand for infrastructure to connect these newfound resources with refineries and processing plants;" thus, the midstream sector, which was expected to mature by 2006, began growing once again, requiring "significant amounts of capital investment to meet growing infrastructure needs." $" 192$

Kenneth B Medlock III, "North American Energy: A Clear Path Forward?" (Presentation delivered at NAFTA at 20: Effects on the North American Market Conference, 5 June 2014) at 76.

GEI, "Impacts and Future," supra note 143 at 8.

Ibid.

Anjli Raval, "US on Track to Become World's Largest Oil Producer," Financial Times (13 February 2018), online: <https://www.ft.com/content/1904fd3c-109a-11e8-8cb6-b9ccc4c4dbbb>.

The Reference case "assumes trend improvement in known technologies along with a view of economic and demographic trends reflecting the current views of leading economic forecasters and demographers" and assumes that current relevant laws remain unchanged during the projection period: US Energy Information Administration, “Annual Energy Outlook 2018 with Projections to 2050" (6 February 2018) at 9, online: <https://www.eia.gov/outlooks/aeo/pdf/AEO2018_FINAL_PDF.pdf>.

Ibid at 19 .

Domm, "Powerful in Energy," supra note 138.

Deloitte Center for Energy Solutions, "The Rise of the Midstream: Shale Reinvigorates Midstream Growth," online: $<$ https://www2.deloitte.com/us/en/pages/energy-and-resources/articles/the-rise-of-themidstream-shale-reinvigorates-midstream-growth.html $>$. 
The US oil relationship with Canada is also expected to deepen if the Keystone XL pipeline is built. ${ }^{193}$ Once built, the Keystone XL pipeline will be able to transport 830,000 barrels a day from Canada, which has the third largest reserves in the world after Saudi Arabia and Venezuela, to the Gulf Coast. ${ }^{194}$ The industry projects that US-Canada gas transportation capacity will increase by 44 to $58 \mathrm{Bcf} / \mathrm{d}$, natural gas liquids transportation capacity will increase by 1.1 to $2.3 \mathrm{~m} \mathrm{~b} / \mathrm{d}$, and pipeline capacity will increase by 4.5 to $6.9 \mathrm{~m} \mathrm{~b} / \mathrm{d}^{195}$

Investments in pipelines are projected to reach anywhere from US\$183 billion to US $\$ 282$ billion. US midstream infrastructure is projected to expand by US $\$ 22.5$ billion to US $\$ 30.0$ billion per year, for a total of US\$471 billion to US\$621 billion over the next 20 years, and create jobs for between 323,000 and 425,000 people per year in the US and Canada, from 2015 to $2035 .{ }^{196}$

\section{GAS RETAIL}

In the late 1990s, natural gas was stored in the summer months, when there is low demand, to mitigate price risks in the winter months when the demand is high and supply is limited. The shale boom decreased gas prices, reduced price volatility, created reliable availability of natural gas supplies, and combined with recent warm winters, has reduced the need for traditional gas storage. The market price signals that prompted storage development in the late 1990s have largely disappeared. "As a result, almost all pending new storage projects and capacity expansions have been delayed or cancelled."197

The Department of Energy, Office of Energy Policy and Systems Analysis (EPSA) predicts a market outlook with:

- $\quad$ very limited demand growth from the residential and commercial sectors;

- $\quad$ modest demand growth from the industrial sector; and

- $\quad$ significant decline in demand from the power sector due to the success of renewable energy. ${ }^{198}$

EPSA predicts total gas demand to decline in the US from an annual average of $68 \mathrm{Bcf} / \mathrm{d}$ in 2016 to $63 \mathrm{Bcf} / \mathrm{d}$ in $2035 .{ }^{199}$

Domm, "Powerful in Energy," supra note 138.

Domm, "One Industry," supra note 145.

ICF International, "North American Midstream Infrastructure Through 2035: Leaning into the Headwinds" (12 April 2016) at 7, online: <https://www.ingaa.org/File.aspx?id=27961\&v=db4fb0ca> . Ibid at 8,11 .

Oak Ridge National Laboratory, "US Natural Gas Storage Capacity and Utilization Outlook" (19 July 2016) at 7 , online: $<$ https://www.energy.gov/sites/prod/files/2017/01/f34/US\%20Natural\%20Gas\%20 Storage $\% 20$ Capacity\%20and\%20Utilization\%20Outlook_0.pdf $\$$.

Ibid at 27.

Ibid. 


\section{ELECTRICITY}

\section{LEGAL FRAMEWORK}

The electricity sector is regulated at the federal, state, and local levels. Because interstate transmission of electricity is a form of interstate commerce, the US electrical infrastructure is considered to be engaged in interstate commerce, and the US constitution provides for federal regulation of interstate commerce. As a result, the federal government regulates interstate transmission. ${ }^{200}$ Some of the most important federal authorities are:

- $\quad$ The Federal Energy Regulatory Commission (FERC)

FERC regulates interstate electricity sales, wholesale electric rates, and hydroelectric facility licensing, among other energy matters affecting interstate commerce. ${ }^{201}$ FERC approves proposed changes and directs the NERC (defined below) to develop modifications to reliability standards. ${ }^{202}$

- $\quad$ The North American Electric Reliability Corporation (NERC)

NERC, under FERC oversight, ensures that the bulk electricity system in North America is reliable, adequate and secure, and develops reliability standards, and has the authority to enforce standards. In 2007, compliance with NERC Reliability Standards became compulsory for bulkpower system owners, operators, and users. $^{203}$

- The US Environmental Protection Agency (EPS)

EPS regulates certain emissions from power generating facilities. ${ }^{204}$

- The Nuclear Regulatory Commission (NRC)

NRC oversees the safety and licensing of nuclear power plants. ${ }^{205}$

- $\quad$ The US Department of Energy (DOE)

DOE is responsible for promoting energy security, as well as scientific and technological innovation. ${ }^{206}$

At the state level, authorities establish construction standards for lower voltage retail distribution facilities, set quality of service standards for the sale of retail electricity to end users, and regulate the prices and terms of electricity service to retail customers. ${ }^{207}$ At the local level, authorities regulate facility sitting and zoning. ${ }^{208}$

Kenneth L Wiseman et al, "Electricity Regulation in the United States: Overview," Practical Law (1 March 2018), online: <https://content.next.westlaw.com/Document/Ieb49d7b91cb511e38578f7ccc38 dcbee/View/FullText.html>. Ibid.

National Renewable Energy Laboratory, "US Laws and Regulations for Renewable Energy Grid Interconnections"'(September 2016), online: $<$ https://www.nrel.gov/docs/fy16osti/66724.pdf $>$ [NREL, US Laws and Regulations]. Ibid at 2 .

Wiseman et al, supra note 200 .

Ibid.

Ibid.

Ibid.

Ibid. 


\section{TRENDS AND OPPORTUNITIES}

Until recently, coal was used to generate almost half of all electricity consumed. Petroleum was briefly used in the 1960s and 1970s to generate electricity, but that trend ended in the $1980 \mathrm{~s}^{209}$ In the $1990 \mathrm{~s}$, as electricity producers faced tighter Clean Air Act ${ }^{210}$ requirements, gas became more popular. The percentage of electricity produced from gas increased from 16 percent in 2000 to 27 percent in 2013. The changes in the source of electricity since NAFTA was signed are demonstrated in a chart produced by the EIA, available online. ${ }^{211}$ The EIA has similarily produced a chart demonstrating the changes in source of electricity since $1950 .^{212}$

The US and Canada have a relatively seamless border regarding electricity transmissions. ${ }^{213}$ There are more than 30 active major transmission connections between the US and Canada, trading approximately US\$3 billion worth of electricity in 2013; the US imports more electricity than it exports, with Canada exporting electricity along the border in many locations; mostly in New England, New York, and the Upper Midwest. ${ }^{214}$ There is an increased interest in utilizing Canadian hydropower to meet US demand, which would also help the US achieve its long-term greenhouse gas reduction goals. ${ }^{215}$

Although the exchange of electricity goes back to 1905 , when privately owned companies shared power over low voltage lines, the exchange of electricity between the US and Mexico is less developed than the exchange between the US and Canada. In 2015, the US government granted Blackstone Group permission to export electricity to Mexico, where customers pay nearly twice as much for power as US customers. ${ }^{216}$ Nonetheless, there is very little cross-border electricity between the US and Mexico, with the exception of cross-border transmission between southern California and Baja California, where electricity is imported from Mexico to supply demand in the San Diego area, and southern and western Texas with the Mexican States of Tamaulipas and Chihuahua - there is potential and opportunity for greater exchange of electricity between the US and Mexico. ${ }^{217}$

\section{E. RENEWABLES}

\section{LEGAL FRAMEWORK}

With the 1973 oil crisis, the US committed to developing solar energy, resulting in Congress passing five energy bills in 1974, which accomplished, among other things: ${ }^{218}$

Ratner \& Glover, supra note 161 at 21.

42 USC \& 7401.

Ratner \& Glover, supra note 161 at 22.

Ibid at 21 .

DOE, Quadrennial Energy Report, supra note 137 at 6-6.

Ibid.

Ibid at 6-7.

Domm, “One Industry," supra note 145.

DOE, Quadrennial Energy Report, supra note 137 at 6-9.

Matthew Sabas, "History of Solar Power" (18 February 2016), online: <https://www.institutefor energyresearch.org/analysis/history-of-solar-power/>. 
- The Solar Heating and Cooling Demonstration Act of 1974 ordered the installation of solar heating and cooling units in federal buildings by 1977 to acclimate the public to the new technology. ${ }^{219}$

- $\quad$ The Solar Energy Research, Development and Demonstration of 1974 created the Solar Energy Coordination and Management Project, directing federal government agencies to improve solar energy technology and to use it to heat and cool government owned buildings, as well as The Solar Energy Research Institute (currently named the National Renewable Energy Laboratory), to conduct research and facilitate the industrial use of solar power. ${ }^{20}$

- The Energy Research and Development Administration, also created in 1974, was responsible for delivering reports on the developments of its solar program and to commercialize solar energy.

President Carter, who labelled the 1970s energy crisis as "the moral equivalent of war,"221 created the Department of Energy in 1977. The following year, Congress passed the Public Utility Regulatory Policies Act, which laid the foundation for future net metering policies in order to make solar viable, affordable, and available to the public. ${ }^{222}$ The Energy Tax Act of 1978 created the commercial investment tax credit (ITC) and the residential energy credit (or residential ITC) to provide financial incentives for the public to purchase solar properties. ${ }^{223}$ Congress also passed the Solar Photovoltaic Energy Research, Development, and Demonstration Act. ${ }^{224}$ More recently, declining oil production led to the passage of the Energy Policy Act of 2005, which provided tax incentives for renewable energy production. ${ }^{225}$ Congress has extended the ITCs several times. ${ }^{226}$

The US uses the following policy vehicles to support renewable energy development: production tax credits, ITCs, grants made under the American Recovery and Reinvestment Act of 2009, ${ }^{227}$ renewable portfolio standards, and renewable generation capacity goals. The US government is aiming to increase its renewable energy sourced electricity from 8.76 percent in 2014 to 30 percent by $2025 .^{228}$

Increasing concerns about the environment and climate change, and declining costs of renewable energy technologies point to an increasingly important role for renewable energy. ${ }^{229}$

University of Virginia Miller Center, "April 18, 1977: Address to the Nation on Energy," online: $<$ https://millercenter.org/the-presidency/presidential-speeches/april-18-1977-address-nation-energy>. Pub L 95-617, 92 Stat 3117.

Pub L 95-618, 92 Stat 3174.

Pub L 95-590, 92 Stat 2513.

Pub L 109-58, 119 Stat 594.

Sabas, supra note 218.

Pub L 111-5, 123 Stat 115 .

Wiseman et al, supra note 200.

NREL, US Laws and Regulations, supra note 202 at 1. 


\section{TRENDS AND OPPORTUNITIES}

The renewable energy sector is expected to grow as renewable energy prices fall. ${ }^{230}$ For instance, the "levelized cost of energy (LCOE) for a wind plant has fallen 66 percent since 2009, while the solar LCOE fell 85 percent."231

The extension of renewable energy tax credits will lead to further growth and the share of renewable energy in energy generation will only increase. The Rhodium Group predicts that renewable energy will "run the table ... with annual capacity additions topping out at an unprecedented $30 \mathrm{GWs}$ in 2021." ${ }^{232}$ Wind generated electric power has especially taken off in recent years, climbing to 168 billion kilowatt hours in $2013 .^{233}$

Another rapidly growing renewable energy source is solar. However, protectionist measures, such as "Buy American" and the recent Section 201 solar trade case, which will result in a tariff or quota on imported solar panels, effectively increasing their prices by 30 percent, could slow down the growth of the solar energy sector and hinder foreign investment. $^{234}$

Open trade among NAFTA signatories in renewable energy sources could increase the sale of US wind-based power to Mexico and Canada, and could also open southern California and the northeastern US to low cost wind, solar, and hydroelectricity from Canada, thereby potentially lowering electricity costs and carbon emissions in these regions. ${ }^{235}$

Another major source of renewable energy in the US, especially in transportation, is ethanol fuel. US ethanol production has increased significantly since 1990, peaking in 2011 at 13.93 billion gallons and more recently at 13.31 billion gallons in $2013 .{ }^{236}$

Regardless of the tax credits, the renewable energy sector will continue to grow. First, because of clean energy and environmental concerns. Second, and more importantly, because renewable energy is increasingly at grid parity with natural gas, is cheaper than coal, and is widespread across the US. ${ }^{237}$ The declining cost and increased competitiveness of renewable energy compared to conventional sources of energy is demonstrated in a chart found in Gavin Bade's 23 January 2017 article, available online. ${ }^{238}$

Gavin Bade, "10 Trends Shaping the Electric Utility Industry in 2017," Utility Dive (23 January 2017) online: <https://www.utilitydive.com/news/10-trends-shaping-the-electric-utility-industry-in-2017/434 $541 />$.

Deloitte Center for Energy Solutions, "2018 Outlook on Renewable Energy: My Take? Marlene Motyka" (2018) at 4, online: <https://www2.deloitte. com/content/dam/Deloitte/us/Documents/energyresources/us-er-renewable-energy-industry-outlook-2018.pdf> [DCES, “2018 Outlook"]. Bade, supra note 230 .

Ratner \& Glover, supra note 161 at 30.

John Fitzgerald Weaver, "Trump Tariff on Import Solar Panels at 30\% - Residential Projects Could Increase \$750-1000, Cost Up to 23,000 Jobs," electrek (22 January 2018), online: <https://electrek.co/ 2018/01/22/breaking-trump-taxes-solar-industry-30-tesla/>.

Goldwyn, supra note 139 at 5 .

Ratner \& Glover, supra note 161 at 29.

Bade, supra note 230.

Ibid. 
While the US intends to withdraw from the Paris climate accord, the withdrawal is unlikely to negatively affect the rapid growth of the renewable energy industry. Nearly 60 percent of Americans opposed the withdrawal, and many cities and states are starting their own clean energy initiatives. ${ }^{239}$ By the end of 2017 , " 170 mayors had pledged their support for a community-wide transition to 100 percent renewable energy in cities, towns, and communities across the United States - and a handful of US cities have already reached that goal." ${ }^{240}$ As of September 2017, 13 states offer green tariffs to customers, where they "can source up to 100 percent of their electricity from renewable resources through a fixed rate." ${ }^{241}$ In addition, by the end of 2017, 117 companies of various sizes had committed to 100 percent renewable procurement. ${ }^{242}$

\section{SUMMARY OF CURRENT NAFTA's CHAPTER 6}

\section{A. Negotiating BaCKGROUND}

Drafting an energy chapter of NAFTA was a sensitive and challenging issue for the three parties involved. The US negotiators desired to secure access to Mexican energy resources while for Mexico, maintaining national control over its resources was of historical and constitutional importance. Meanwhile, Canada and the US had an energy agreement that was in turmoil as a result of what was thought to be a scarcity of resources. ${ }^{243}$

Of significance was the fact that Chapter 6 affirmed the respect the parties had for each of their respective constitutions. For Mexico, in particular, this honored the constitutional limitations it imposed on foreign investment in the oil and gas sector.

The 1970s and 1980s marked a turbulent time for the US-Canada relationship, specifically with regards to natural resources. ${ }^{244}$ Like Mexico, the Canadian government was concerned that foreign investors, primarily the US, had over invested in Canadian natural resources and thus Canada implemented restrictions on foreign investment. ${ }^{245}$ Allan Gotlieb, the former Canadian Ambassador to the US, "reported that when he took office in the early 1980s, the energy relationship was the principal cause of the very sour diplomatic climate between the two countries." ${ }^{246}$ Many of the concerns of the 1970s and 1980s were addressed in the FTA. NAFTA was therefore not the first step in repairing the relationship, but it was a further step in the right direction.

DCES, "2018 Outlook," supra note 231 at 3-4.

Ibid at 4 [footnotes omitted].

Letha Tawney et al, "5 Emerging Trends for Corporate Buyers of Renewable Energy" (September 2017), online: World Resources Institute <https://www.wri.org/blog/2017/09/5-emerging-trendscorporate-buyers-renewable-energy>.

DCES, "2018 Outlook," supra note 231 at 4.

Barry Appleton, Navigating NAFTA: A Concise User's Guide to the North American Free Trade Agreement (Scarborough, Ont: Carswell, 1994) at 39.

Reinier Lock \& Bill F Kryzda, "Mexico-United States Energy Relations and NAFTA" (1993) 1 US-Mex LJ 235 at 237.

Ibid.

Ibid. 


\section{B. Summary of Key Provisions}

Chapter 6 of NAFTA covers the four basic areas of energy trade: oil (in both crude oil and refined products), natural gas, electricity, and coal. ${ }^{247}$ Article 601 of Chapter 6, entitled "Principles," establishes two main theses:

[T] he "desire to strengthen the important role that trade in energy and basic petrochemicals goods play in the free trade area and to enhance this role through sustained and gradual liberalization" and the recognition of the "importance of having viable and internationally competitive energy and petrochemical sectors to further their individual national interests." 248

Importantly, included in "Principles" is language which states that the parties acknowledge their "full respect for their Constitutions." 249

\section{OBLIGATIONS}

NAFTA establishes a number of obligations upon parties regarding the treatment and supply of energy which can be divided into two categories: (1) Articles 603 and 604 prohibit the use of barriers to imports and exports, either in the form of quotas, maximum and minimum import and export prices, or export duties; (2) Articles 605 and 607 establish a limit on the parties' latitude to implement trade restrictive measures "under exceptional circumstances to a greater extent than what [was] permitted under the GATT." 250

While the above demonstrates a divergence from the GATT, much of Chapter 6 and its associated articles were developed based on GATT principles. ${ }^{251}$ For example, Article 603 which forms a central component of the liberalization of energy under NAFTA, incorporates GATT principles with respect to trade in petrochemicals. Specifically, Article 603(2) states: "[t]he Parties understand that the provisions of the GATT incorporated in paragraph 1 prohibit, in any circumstances in which any form of quantitative restriction is prohibited, minimum or maximum export-price requirements and ... minimum or maximum importprice requirements." 252

Consequently, parties must not impose minimum or maximum export or import price requirements unless necessary to enforce countervailing or anti-dumping duty orders. ${ }^{253}$ Notwithstanding the aforementioned, "Parties may adopt or maintain restrictions on energy imports or exports from non-Parties." ${ }^{254}$ Where a party imposes restrictions on non-parties, other NAFTA parties ought to avoid undue interference with it. ${ }^{255}$ Similarly, Article 603(5) allows parties to administer a system of import and export licensing for energy and basic petrochemicals if such a system is consistent with the Agreement.

$\begin{array}{ll}247 & \text { Appleton, supra note } 243 \text { at } 39 . \\ 248 & \text { Herrán \& Poretti, supra note } 184 \text { at } 357 . \\ 249 & \text { NAFTA, supra note } 1 \text {, art } 601(1) . \\ 250 & \text { Herrán \& Poretti, supra note } 184 \text { at } 359 . \\ 251 & \text { Appleton, supra note } 243 \text { at } 40 . \\ 252 & \text { NAFTA, supra note } 1 \text {, art } 603(2) . \\ 253 & \text { Ibid. } \\ 254 & \text { Appleton, supra note } 243 \text { at } 40 . \\ 255 & \text { NAFTA, supra note } 1 \text {, art } 603(3) .\end{array}$


Article 604 holds that a party is prohibited from adopting or maintaining "any duty, tax or other charge on the export of any energy or basic petrochemical good to the territory of another Party, unless" the same measure is applied domestically and to all exports. ${ }^{256}$ Similarly, Article 605 creates a proportionality provision which means that the US and Canada cannot reduce access to each other's natural resources without an equivalent reduction in domestic access to the same product. Consequently, any cut in oil exports to the US would require a corresponding cut to Canadian domestic supplies. This provision, along with other restrictions, is generally subject to a very narrow national security exemption. ${ }^{257}$ Article 607 establishes a special definition of national security in the context of the Energy chapter - it allows a party to restrict imports or exports to the extent necessary to:

a) Supply a military establishment of a Party or enable fulfillment of a critical defense contract of a Party;

b) Respond to a situation of armed conflict involving the Party taking the measure;

c) Implement national policies or international agreements relating to the nonproliferation of nuclear weapons or other nuclear explosive devices; or

d) Respond to direct threats of disruption in the supply of nuclear materials for defense purposes. $^{258}$

\section{REGUlATORY MEASURES}

The negotiators of NAFTA created an important regulatory provision, Article 606, which establishes an obligation on energy regulatory bodies to apply measures consistent with NAFTA's imposed obligations for the national treatment of import and export restrictions and export taxes.

\section{NEgOtiating OBJECTIVES FOR CHAPTER 6 AND SPECTRUM OF LIKELY OUTCOMES FOR AN ENERGY CHAPTER 53}

\section{A. Canada}

Canada has articulated its interest in renegotiating a Chapter on energy. Ultimately, Canada is interested in the oil and gas industry and ensuring its access to the international market and the ability to build a pipeline that runs southwest. NAFTA negotiations offer an opportunity to help secure the development of a pipeline project to move Alberta oil to US markets. Thus far, however, there has been little indication that Canada has tabled any concrete proposals in this regard.

Notwithstanding the above, a source (as stated in Politico) illustrated in "The Steel Elephant in the Room at NAFTA Round 7," that the renegotiation of NAFTA will include a 
standalone Chapter on energy which "will focus on regional cooperation and integration" with the intention of "more interconnectivity across the networks of energy in North America. ${ }^{, 259}$ Ultimately, the three parties have similar goals: energy security, pipeline access, and cheaper power, and it is one of the few topics that President Donald Trump has not targeted with his American First Policy. ${ }^{260}$

Mexico's relatively recent constitutional reform, which allows for foreign investment in the energy industry, provides another area for renegotiation. That is, the recent reforms could bring Mexico's energy sector under the same, or similar rules as those governing Canada and the US. In particular, the new section need not include a section which disallows foreign investors in Mexico.

Interestingly, for all three parties, North America has become the only region that is nearly energy independent. ${ }^{261}$ Consequently, renegotiating an energy Chapter could serve to all parties' benefit.

\section{B. UNITED STATES}

The Edison Electric Institute and Canadian Electricity Associations' joint position published in a joint report was to preserve NAFTA Chapter 6 in the renegotiations, with Mexico becoming a full partner under Chapter $6 .{ }^{262}$ For the US energy industry, NAFTA and "trading energy with our neighbors to the north and south provides tremendous benefit to the United States' economic and energy security." 263 "[T] nothing to fear from the North American Free Trade Agreement (NAFTA) — and a lot to gain." ${ }^{264}$ The US Chamber of Commerce has voiced concern "that withdrawing from NAFTA would impose unacceptably high costs" for the US. ${ }^{265}$

In the summary of US objectives, published by the United States Trade Representative (USTR) in July and November 2017, the USTR did not mention Chapter 6. Regarding the energy sector, the USTR stated that its objective in the renegotiation is to "[p]reserve and strengthen investment, market access, and state-owned enterprise disciplines benefitting energy production and transmission and support North American energy security and independence, while promoting continuing energy market-opening reforms.",266

Megan Cassella, "The Steel Elephant in the Room at NAFTA Round 7," Politico (5 March 2018), online: <https://www.politico.com/newsletters/morning-trade/2018/03/05/the-steel-elephant-in-theroom-at-nafta-round-7-123039>.

Rona Ambrose, "Renewed NAFTA has Potential to be a Big Three-Way Win for Energy," Calgary Herald (26 January 2018), online: < https://calgaryherald.com/opinion/columnists/ambrose-renewednafta-has-potential-to-be-a-big-three-way-win-for-energy>.

Ibid.

Sergio Marchi, "Regional Energy Security \& Collaboration; Moving from a Free Trade Area, to a North American Community" (Remarks delivered at the Washington International Trade Association Energy and the NAFTA Panel Discussion, 7 December 2017) at 7, online: <https://cea-ksiu6qbsd.netdnassl.com/wp-content/uploads/2017/12/Washington-International-Trade-Association-WITA.pdf>. GEI, "Impacts and Future," supra note 143 at 1.

Ibid at 10 .

Ibid at 11 .

Office of the United States Trade Representative, "Summary of Objectives for NAFTA Renegotiation" (November 2017) at 16. 
While some high priority NAFTA renegotiation chapters, such as labour mobility and dispute settlement, are relevant to the energy industry, Chapter 6 is not a high renegotiation priority for the US.

\section{IMPLICATIONS OF A NAFTA TERMINATION}

With the political landscape surrounding NAFTA, its termination is not impossible. The termination of NAFTA would cause a rise in tariffs, supply chains to be shaken up, and an increase in prices for various consumer goods.

Under the current NAFTA, parties pay nothing on most goods that cross the border. Without an agreement, the three parties could raise tariffs to as high as 150 percent, which would cause prices to spike, thereby affecting company profits. All three countries are WTO members and therefore, tariffs could revert to those levels. That is, tariffs on agricultural exports to Mexico could rise to 15 percent for wheat, 25 percent for beef, and 75 percent for chicken and potatoes. ${ }^{267}$ Such an increase could have the effect of raising consumer prices. The current supply chains that have developed since 1994 between the three countries would be changed and potentially ruined.

Alternatively, withdrawal from NAFTA could set the stage for a new trade pact or an entirely new trade agreement. Ultimately, the implications of NAFTA terminating are unknown.

\section{Conclusions AND RECOMmendations}

NAFTA remains unique among international trade agreements and has benefited the three parties for over two decades; in 2015, total trilateral merchandise trade, as measured by the total of each country's imports from its other two NAFTA partners, amounted to over US $\$ 1.0$ trillion. That represented 28 percent of the world's GDP with less than 7 percent of the world's population. Since NAFTA's initiation, the North American economy has expanded, with the combined GDP of the parties reaching US\$21.1 trillion in $2016 .^{268}$

NAFTA continues to be a milestone agreement in international trade negotiations. NAFTA is the first trade agreement of its kind which integrated the economies of developed and developing countries. ${ }^{269}$ NAFTA also creates a significant enhancement in scope and application of comprehensive trade agreements dealing with goods, services, and investment. Lastly, NAFTA acknowledges the link between trade and the environment.

Specifically regarding energy, NAFTA has resulted in North America becoming almost entirely energy self-sufficient. With Canada's abundant supply of natural resources, America's recent "shale revolution," and Mexico's shift in foreign investment laws, the

Ana Swanson \& Kevin Granville, "What Would Happen if the U.S. Withdrew From NAFTA,” The New York Times (12 October 2017), online: <https://www.nytimes.com/2017/10/12/business/economy/whatwould-happen-if-the-us-withdrew-from-nafta.html>.

Government of Canada, "North American Free Trade Agreement (NAFTA)"(14 February 2017), online: $<\mathrm{https}: / / \mathrm{www}$.international.gc.ca/trade-commerce/trade-agreements-accords-commerciaux/agr-acc/n afta-alena/fta-ale/info.aspx?lang=eng\&amp $>$.

Appleton, supra note 243 at 4. 
energy market has gone through significant changes, many of which are benefiting the parties.

Ultimately, NAFTA has provided numerous opportunities to businesses, industries, and workers (more than five million jobs have been created in Canada since it was executed). The agreement was designed to lead to more efficient use of North American resources land, labour, and technology.

While the future of NAFTA is unknown, the past and its success is clear; millions of jobs have been created in all party states, and GDP has increased substantially. 